\title{
GLAGOLJSKA MADRIKULA SVEĆENIČKE BRATOVŠTINE ZADARSKIH OTOKA VEČERE GOSPODNJE (COENA DOMINI) IZ UGLJANA OD POČETKA 17. DO POČETKA 19. STOLJEĆA
}

\author{
Grozdana FRANOV-ŽIVKOVIĆ \\ Zavod za povijesne znanosti HAZU u Zadru \\ Zadar, Hrvatska
}

\author{
UDK: 272-774-46(497.5 Ugljan) \\ DOI: $10.21857 / 94 \mathrm{kl} 4 \mathrm{cz} 02 \mathrm{~m}$ \\ Izvorni znanstveni rad \\ Prihvaćeno: 27. ožujka 2020.
}

$\mathrm{Na}$ zadarskom području u prošlosti nalazimo više svećeničkih bratovština. Njihov konačan broj do sada nije poznat, kao što nije obrađeno djelovanje većine ovih bratovština. U Zadru nalazimo osam svećeničkih bratovština, na otocima šest, a na kopnenom dijelu četiri. U članku će se posebno staviti naglasak na otočku Bratovštinu Večere gospodnje iz Ugljana, njezine ciljeve i zadatke na osnovi glagoljske madrikule nedavno pronađene u Trstu. Bratovština je osnovana (ili obnovljena) 1617. godine, a članovi ove bratovštine bili su svećenici sa sjeverozapadnog dijela otoka Ugljana, prvenstveno iz mjesta Ugljan, Lukoran, Sutomišćica, Poljana i Preko, te dijelom svećenici s otoka Oliba, Molata, Iža, Premude, Silbe i sjeverozapadnog dijela Dugog otoka.

Ključne riječi: svećeničke bratovštine, glagoljske madrikule, Ugljan, Bratovština Večere Gospodinove, početak 17. do početka 19. st.

Kao pobožne zajednice vjernika i svećenika kod kojih se u prvom redu prakticira pobožnost i karitativna djelatnost, ${ }^{1}$ ali koje ujedno imaju i jaku gospodarsku, socijalnu, političku i kulturnu ulogu, ${ }^{2}$ bratovštine (skule) na zadarskom području javljaju se još od 12. stoljeća. ${ }^{3}$ Među njima razlikujemo obrtničke i vjerske bratovštine, koje opet mogu biti svećeničke i laičke. Laičke se dijele na mješovite muško-ženske, samo muške te samo ženske bratovštine. Već u srednjem vijeku spominju se bratovštine zadarskih otočkih i kopnenih svećenika. Svaka bratovština ima svoja posebna obilježja (zastave (bandire), odijelo, boje

1 Tonija ANDrić, Socijalna osjetljivost obrtničkog sloja u Splitu sredinom 15. stoljeća, Historijski zbornik, god. LXVI, Zagreb, 2013., br. 1, 1 - 23.

2 Irena Benyovsky, Bratovštine u srednjovjekovnim dalmatinskim gradovima, Croatica Christiana Periodica, god. XXII, br. 41, Zagreb, 1998., 141. Prva svećenička osnovana je u Dubrovniku 1247., zatim u Zadru 1296.

3 Vladislav Cvitanović, Bratovštine grada Zadra, Zbornik Zadar, Zagreb, 1964., 457 - 470; Lovorka Čoralić, Izvori i literatura o bratovštinama u Dalmaciji od srednjeg vijeka do pada mletačke republike, Croatica Christiana Periodica, god. XV, br. 27, Zagreb, 1991., 88 - 96. 
svijeća), ${ }^{4}$ ima svoju bratovštinsku (bratsku) kuću ili neko drugo mjesto gdje se članovi sastaju. U njima se održavaju godišnje i izborne skupštine (brašćine, ${ }^{5}$ bratski stol), ali i druge vrste sastanaka tijekom godine. U laičkim bratovštinama svećenici ( redovnici) ${ }^{6}$ su rijetko članovi upravnog tijela bratovštine, više su članovi suda časti ili prokaraturi Crkve. ${ }^{7} \mathrm{U}$ upravnim tijelima svećeničkih bratovština, iako su primali i ograničeni broj laika, bili su isključivo svećenici. Uz muške laike, u pojedine svećeničke bratovštine bile su primane i žene. Na zadarskom području imamo za primjer svećeničku Bratovštinu Gospe od Milosrđa, a i jedna od seoskih svećeničkih bratovština, Svetog duha Ravnih kotara, u svoje je redove primala i žene (sestre). ${ }^{8}$

Svećenici su svoje bratovštine osnivali s ciljem međusobnog povezivanja, druženja, pomaganja te radi zajedničkog istupanja pred civilnim i crkvenim vlastima. U ovim bratovštinama nedostaje ova gospodarska komponenta, dok humanitarnu i socijalnu, kao i političku posjeduju. Svećenici su bili učlanjivani i u obične bratovštine, što se vidi po madrikulama bratovština. U mnogim madrikulama postojali su posebni popisi svećenika, a posebni svjetovnih muških i ženskih članova, a po kapitulima laičkih bratovština vidljivo je da su svećenici (redovnici) imali posebna zaduženja (služenje mise, molitve za živu i mrtvu braću, vođenje bratovštinske evidencije, odlazak na hodočašća i njihova organizacija). ${ }^{9}$

4 Npr. bratimi Bratovštine sv. Mihovila u Vrsima svoje su svijeće na krajevima bilježili zelenom bojom: AZDN, Glagoljska Madrikula svetog Mihovila u Vrsima (kod Nina), 1700. - 1822, 11: „Bija(še) i skula od oltara s(vetoga) Trojstva i davahu se obiti i strošak činjaše se kako i u skuli s(vetoga) Mihovila. I gorahu se sviće koje bijahu biližene na kraju zelenin. Videći braća i ja parok da veliki strošak čini crkva, ukinusmo braštinu S(vetoga) Trojstva.“

5 Katkad se i same bratovštine na osnovi naziva za godišnje skupštine nazivaju brašćine.

6 Po popisima članova u većini madrikula bratovština zadarskog područja vidljivo je da se svi svećenici nazivaju redovnicima, bilo da je riječ o župnicima, biskupima, fratrima i dr.

7 Primjeri u: Grozdana Franov-ŽIVković, O kaljskim bratovštinama u razdoblju od 14. do 19 st., Zbornik Kali, Zadar, 2017., 175 - 236.

8 V. Cvitanović, Bratovštine grada Zadra, 465 - 466. Bratovština svećeničke bratovštine Gospe od Milosrđa 1493. (prijepis 1797.) primala je žene; Vilma PEZELJ, Žene u bratovštinama srednjovjekovnih dalmatinskih gradova, Zbornik radova Pravnog fakulteta u Splitu, god. 47, br.1 (95), Split, 2010., 155 - 173, 162: „1496. među članovima je bilo samo 20 svećenika. Svjetovnjaci oba spola bili su dionici duhovnih blagodati i pokapani su u zajedničku grobnicu, ali nisu imali nikakvih udjela u upravi društva.“

9 O tome u nekoliko članaka o laičkim bratovštinama zadarskog područja: Grozdana FrANovŽiv ković, Bratovštine (Skule) župe sv. Mihovila u sv. Filipu i Jakovu u razdoblju od 17. do 19. st., Sv. Filip Jakov, 2013.; Grozdana Franov-ŽIvković, Bratovštine (skule) župe sv. Eufemije (Fume) u Sutomišćici na Otoku Ugljanu u 18. st., Zbornik Odsjeka za povijesne znanosti Zavoda za povijesne $i$ društvene znanosti HAZU u Zagrebu, 27, Zagreb, 2009., 165 - 227; Grozdana Franov-ŽIvković, Bratovštine (skule) župe Blažene Gospe od Luzarija u Preku na otoku Ugljanu u 18. st. i 19. st., Radovi Zavoda za povijesne znanosti HAZU u Zadru, 52, Zagreb-Zadar, 2010., 231 - 259; Grozdana FrANovŽıv ković, Bratovština (skule) župe sv. Ivana Krstitelja u Tinju i župe sv. Petra i Pavla u Bubnjanima 


\section{SVEĆENIČKE BRATOVŠTINE ZADARSKOG PODRUČJA}

$\mathrm{Na}$ zadarskom području, na temelju postojećih podataka i sačuvanih evidencija, nalazimo sljedeće svećeničke bratovštine: ${ }^{10}$

- "Bratovština sv. Stjepana". Svećenička bratovština koja se spominje u srednjem vijeku. Šimun Miroević, župnik u zadarskom varošu (,in burgo“) piše oporuku 23. kolovoza 1506., a za izvršioce oporuke određuje Bartola, kapelana u Lazaretu izvan zidina, kao predstavnika bratovštine svećenika u Sv. Stjepanu, ${ }^{11}$ Tomana iz Ugljana, kao predstavnika bratovštine otočnih svećenika ${ }^{12} \mathrm{i}$ Jerolima Cedolinisa iz Zadra. ${ }^{13}$ Ako koji izvršitelj umre, neka ga braća zamijene novim. Iz oporuke je vidljivo da je bio bratim i svećeničke bratovštine na zadarskim otocima ${ }^{14}$ i svećeničke bratovštine u crkvi sv. Stjepana. Ostavlja svećeniku koji će podučavati njegova nećaka Grgu par volova, koji će se kasnije prodati i uložiti u izgradnju crkve sv. Stjepana. Ova svećenička bratovština u Sv. Stjepanu možda je bratovština glagoljaša grada Zadra, što se vidi u oporuci Šimunova

u 18. stoljeća, Radovi Zavoda za povijesne znanosti HAZU u Zadru, 53, Zagreb-Zadar, 2011., 163 187; Grozdana Franov-Žıv ković, Glagoljska Madrikula sv. Jakova u Solinama na Dugom otoku (1750.-1826), Radovi Zavoda za povijesne znanosti HAZU u Zadru, 51, Zagreb-Zadar, 2009., 137 - 159; Grozdana Franov-Žıvković, Danijela Deković, Prilozi istraživanju svakodnevnog života Vinjerca na temelju glagoljske knjige bratovštine sv. Antuna padovanskog i ostalih glagoljskih vrela od kraja 17. do početka 19. stoljeća, Radovi Zavoda za povijesne znanosti HAZU u Zadru, 6, ZagrebZadar, 2018., 205 - 248; Grozdana Franov-Žıvković, Glagolitic Confraternities Books of the Zadar Area and their Value as Historical Documents, Authority, Provenance, Authennticity, Evidence, selected papers from conference Authority, Provenance, Authenticity, Evidence, Zadar, Croatia, october 2016., ur. Mirna Willer, Anne J. Gilliland, Marijana Tomić, Zadar, 2018., 383 - 415; Grozdana Franov-Žıvković, Ivica Vigato, Svakodnevni život Vlašića na otoku Pagu na osnovu zapisa iz glagoljskog kvaterana bratovštine Sv. Jerolima/Sv. Sakramenta i ostalih glagoljskih rukopisa iz 18. stoljeća, Radovi zavoda za povijesne znanosti HAZU u Zadru, 61, Zagreb-Zadar, 2019.

10 Cvitanović spominje samo šest svećeničkih bratovština. Vladislav Cvitanović, Bratovštine grada Zadra, 457 - 470; Petar Runje, Duhouni život na zadarskim otocima u kasnome srednjem vijeku, Zadar, 2008.; P. Runje, Glagoljica u zadarskoj nadbiskupiji u srednjem vijeku, Zadar, 2005.; Grozdana Franov-ŽIv ković, Društvena slika ugljanskih sela od 15. do 18. stoljeća prema podacima iz glagoljskih vrela, doktorski rad, Zadar, 2013.; G. Franov-Žıvnović, Bratovštine (skule) župe Blažene Gospe od Ruzarija u Preku na Otoku Ugljanu u 18. st. i 19. st., 231 - 259; G. FranovŽıv коvić, Bratovštine (skule) župe sv. Eufemije (Fume) u Sutomišćici na Otoku Ugljanu u 18. st., $165-227$.

11 Sada crkva sv. Šime.

12 Nije navedeno kako se zvala ova otočka svećenička bratovština.

13 P. Runje, Glagoljica u zadarskoj nadbiskupiji u srednjem vijeku, 162, 163, 202, 204.

14 Po prezimenu je Šimun mogao biti iz Ugljana. Postoji još svećenika rodom iz Ugljana s ovim prezimenom. Npr. Don Luka Marojević ili Marojić. Grozdana Franov-Žıvković, Načini evidentiranja podataka u glagoljskim matičnim knjigama pisanima do 1825 . godine na zadarskom području, Povijesni zbornik - godišnjak za kulturu i povijesno naslijeđe, br. 4 (God. III), Osijek, 2009., 79 - 124 . 
nećaka Grge Mirojića pok. Pavla, koji je bio župnik u predgrađu Zadra. On moli petoricu svećenika da izgovore po jednu grgurevsku misu za njegovu dušu u crkvi sv. Stošije. To su sljedeći svećenici: Jerolim Gladović, Nikola Žubrić, Andrija Gorušić, Juraj Oplanić i Mihovil Radinić. Želi biti pokopan u istoj crkvi sv. Stošije, gdje mu je pokopan i stric. Spominje bratovštinu svećenika glagoljaša grada Zadra (littere Illyrice), a sam za sebe kaže da je njezin član. Očito je i on bio učlanjen, poput strica, u obje bratovštine. ${ }^{15}$ Sačuvan je prijepis madrikule bratovštine, koja se čuva u Stalnoj izložbi crkvene umjetnosti u Zadru. Okove njezinih korica napravio je Stjepan Venzon 1588. godine od iskucanog i pozlaćenog srebra; okovi su dimenzije $26,5 \times 19,5 \mathrm{~cm} .{ }^{16}$

- "Bratovština svećenika u sv. Donatu". ${ }^{17}$ U Donatu su se sastajale brojne zadarske bratovštine, pa među njima i svećenička. Cvitanović spominje da je postojala od 1332. i da je bila najstarija zadarska svećenička bratovština. ${ }^{18}$ Petar Runje također spominje svećeničku bratovštinu ove crkve te da su se u njoj sastajali glagoljaši i da se u njoj redovito glagoljalo, pa tako piše o zborovima svećenika glagoljaša u Sv. Donatu. Godine 1504. kopneni i otočki svećenici glagoljaši zajednički nastupaju protiv nekih odredbi nadbiskupa i zadarskog kaptola, a sastaju se nekoliko puta u crkvi sv. Donata. ${ }^{19}$ "Osamdesetih godina 15. stoljeća neki vjernici u svojim oporukama ostavljaju svećenicima glagoljašima oporučno da služe sv. mise za spokoj njihovih pokojnih i njih samih u gradskim crkvama. U oporuci don Juraj „Chiuriliza“, stanovnik Zadra, 3. svibnja 1480. određuje da ga pokopaju u crkvi sv. Donata, a četrdeset sv. misa neka izgovori

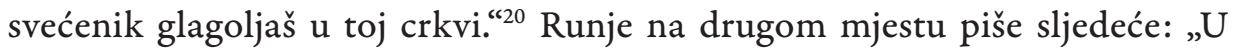
crkvi svetog Donata glagoljalo se jer nadbiskup Vallaresso izričito veli da tu mogu slaviti, ako je pogreb, i glagoljaši.“21

- "Bratovština sv. Luzarija".22 Sačuvana evidencija nalazi se u Arhivu Zadarske nadbiskupije. Bratovština je osnovana 1248. godine, osnovali su poglavlje: Zlatarstvo i tekstil, 102.

17 Vidi članak G. Franov-Žıvnović, Zapisi iz knjige Bratovštine Gospe od Sniga u Sv. Donatu, Glagoljica u Zadru (drugi dio), Glasilo udruge glagoljaša Zadar Slovo rogovsko, br. 5, Zadar, 2017., 17. stoljeća.

19 Petar Runje, Glagoljica u zadarskoj nadbiskupiji u srednjem vijeku, 174 - 175.

20 Petar Runje, O knjigama hrvatskih glagoljaša, Zagreb, 1997., 12

21 U knjizi Glagoljica u zadarskoj nadbiskupiji u srednjem vijeku, 94.

22 HR-AZDN-15, Bratovština Blažene Djevice od Svetoga Ružarija 1644. - 1874., (Confraternitá della Beata Virgine del Santo Rosario, Scuola della Beata Virgine del Santo Rosario); V. Cvitanović, Bratovštine grada Zadra, 463; Vodič arhiva Zadarske nadbiskupije, priredili: Oliver Modrić i Josip Kolanović, Zadar, 2013., 66, 67. 
je dominikanci kad su stigli u Zadar, tako da joj je prvotno sjedište bilo u crkvi sv. Dominika. Pravila su potvrđena 1604. i 1621. godine. Za vrijeme francuskih vlasti 1807. crkva sv. Dominika je zatvorena, a bratovština se seli u crkvu sv. Šime. Od 1811. djeluje u okviru bratovštine sv. Sakramenta, a 1858. se osamostaljuje. Prve nedjelje u mjesecu listopadu bratovština je imala javnu procesiju u gradu, a u crkvi sv. Dominika imala je svoje crkvene grobove. Godine 1807. imala je 2140 članova.

- "Bratovština Gospe od Milosrđa". Za ovu je bratovštinu u Državnom arhivu u Zadru sačuvana madrikula pod nazivom „Libar Godof bratia i sestar toliko Redofnikof choliko Sfitovnikov“i dalje se navodi: „u koyem su upisana Gimena i Choi se napovidy u svaku sridu od Godisca, kad ne prihodi koj blagdan, chi zapricuye, dasse ne moxe chantati od Martvih Miss; a to za bratiu i sestre ove postovane Schupschine aliti Schulle B. V. Marie od Milosardia. V Zadru bi ispisano Godischie Gospodinovo 1797. Pod Gastaldom Gosp(odino)m D(o)n Ivanom Vlacovich, Ant, Battara scrip." Kapituli su pisani na hrvatskom jeziku i latinici, a objavio ih je V. Cvitanović koji navodi da je postojala još jedna bratovština D. M. od Dobre radosti koja se kasnije nazivala Gospe od Milosrđa, koju ne treba miješati s ovom prvom bratovštinom. „Bratovština Gospe od Milosrđa. Ova svećenička bratovština zvala se prvotno D. M. od Dobre radosti i djelovala je $\mathrm{u}$ istoimenoj crkvi (del Buon gaudio, blizu Terraferma; porušena je 1704), a poslije 1630. prešla je u crkvu sv. Šime. Ustanovljena je 1493. Pravila joj se sastoje od 12 kapitula. Potvrdili su je nadbiskupi Florio (1651) i Parzago (1677). Svrha joj je bila častiti na osobiti način D. Mariju, neoskvrnjeno začetu, pomagati djelima kršćanske ljubavi bolesnu braću za života i po smrti. U početku svaki svećenik nastanjen u Zadru mogao je biti njezin bratim, a od 1496. samo 20 svećenika moglo je biti upisano. Primani su i svjetovnjaci (kao dobročinci muški i ženske) u članstvo, a bili su dionici duhovnih blagodati i pokapani su u zajedničku grobnicu, ali nisu imali nikakva udjela u upravi društva. Bila je vrlo cijenjena i ugledna zbog crkvenih ličnosti (i sam nadbiskup bio je redovito njezin bratim) kao i zbog brojnih privilegija te bogatih posjeda i prihoda. Na čelu društva stajao je gastald i 2 skrbnika, koji su se birali svake godine. Sastanke ( 5 puta godišnje) držali su u kapeli Gospe Začeća, a kasnije u sakristiji (riznici) sv. Šime. Imala je svoju kapelicu s mramornim oltarom. U čast D. Marije obavljala je razne vjerske funkcije i služila mnogobrojne mise za umrlu braću. Prihodi društva bili su: globe, taksa svjetovne braće (1 dukat pri upisu i 4 soldi godišnje), oporučne ostavštine i dobrotvori bratovštine. Otkad joj je početkom XIX stoljeća propala glavnica, jer je bila uložena u državne obveznice, bratovština 
nazaduje; god. 1842. imala je samo 4 brata, i malo zatim je nestala. Neke njene zemlje uživao je župnik sv. Šime.“23

- "Bratovština B. D. Marije od ljubavi (della Caritá)". ${ }^{4}$ Ovu bratovštinu također spominje Cvitanović, i to kao jošjednu svećeničku bratovštinu sa sjedištem u Sv. Donatu. Bratovština je početkom 16. stoljeća imala sjedište u crkvi sv. Marije Velike, a kad je crkva 1570. godine bila porušena, bratimi su sjedište prebacili u crkvu sv. Donata. Godine 1801. spojila se s novoosnovanom svećeničkom bratovštinom Bratske pripomoći, a njihovo sjedište prebačeno je u katedralu sv. Stošije. Njima se 1803. godine priključila Bratovština brodograditelja, koja je osnovana još 1479. godine, a godine 1669. zaštitnik su joj bila sv. Trojica. Ranije se zvala Bratovština D. M. od Očišćenja, zatim Bratovština D. M. od ljubavi i dobre radosti. God. 1594. potvrdio ju je nadbiskup Molin. Imala je samo 12 bratima. Dužnost joj je bila održavanje vlastitih oltara, pjevanje mise na njezinu svetkovinu (2. 2.) te dati reći 12 misa u župnoj crkvi sv. Eufemije. Prije 1856. bila je isključivo bratovština zadarskih svećenika, a nakon toga su u nju primani i seoski svećenici. I žene su bile članice.

- "B. D. Marija od dobre radosti". ${ }^{25}$ U Vodiču Arhiva Zadarske nadbiskupije o bratovštini je zapisano sljedeće: „Bratovština Blažene Djevice od Dobre radosti ustanovljena je 1510., potvrdio ju je 1517. nadbiskup Molin te ponovo 1594. nadbiskup Minucci. Imala je samo 12 bratima i to kanonika i svećenika koji su vršili funkcije u katedrali Sv. Stošije. Prihodi su joj bili nasljedne daće, kamate glavnica i najmovi vlastitih kuća. Oko 1760. izgradila je vlastiti mramorni oltar u katedrali na kojemu se nalazi uljena slika Blažene Djevice Marije, obložena srebrom. Bratovština je najvjerojatnije ukinuta za vrijeme francuske uprave (1806. - 1813).“ Cvitanović na str. 467 uz ove iste podatke dodaje da je ovo peta zadarska svećenička bratovština te da je postojala do 1821. godine. Gradivo ovog fonda sastoji se od jedne

23 V. Cvitanović, Bratovštine grada Zadra, 465; HR-DAZD-335, Bratovštine u Dalmaciji 1406. 1880.; G. Franov-Žıvković, Glagoljski zapisi u dokumentaciji svećeničke bratovštine Blažene Djevice od Dobre radosti (Confraternita della Beata Vergine del Buongaudio). Glagoljica u Zadru (treći dio), Glasilo Udruge glagoljaša Zadar Slovo Rogovsko, Zadar, 2018., br. 6, 14 - 17; Vodič Državnoga arhiva u Zadru, Državni arhiv u Zadru, ur. Josip Kolanović, Zadar, 2014., knjiga II, 467 $-471$.

24 V. Cvitanović, Bratovštine grada Zadra, 466, 467, 468, 461.

25 G. Franov-Žıv ković, Zapisi iz knjige Bratovštine Gospe od Sniga u Sv. Donatu, 18; V. Cvit anović, Bratovštine grada Zadra, 461, 466, 467; Grozdana Franov-Žıvković, Glagoljski zapisi u dokumentaciji svećeničke bratovštine Blažene Djevice od Dobre radosti (Confraternita della Beata Vergine del Buongaudio). Glagoljica u Zadru (treći dio), 15. U Arhivu Zadarske nadbiskupije čuva se dio dokumentacije zadarske svećeničke bratovštine Blažene djevice od Dobre radosti 1554. - 1821. Sačuvana je jedna kutija i jedna knjiga (HR-AZDN-14). 
knjige prihoda i rashoda bratovštine 1667. do 1808. i jedne kutije s raznim dokumentima, dopisima, računima, inventarima, knjižicama primanja i parnica oko posjeda.

- "Zadruga bratske pomoći”. ${ }^{26}$ Svrha joj je bila skupljanje novčane pomoći za potrebite svećenike.

- Moguće je da je svećenička bratovština bila i ona "Sv. Karla Boromejskog" ili Bratovština krśćanskog nauka, koja je oltar imala u katedrali, a sastanci su se održavali u Svetom Donatu, a cilj joj je bio podučavanje dječaka kršćanskom nauku. ${ }^{27}$ Nije sačuvana evidencija ove bratovštine. ${ }^{28}$

Svećeničke bratovštine kopnenog dijela zadarskog područja spominju se i u srednjem vijeku. Luka Vlatković, župnik Stomorina sela, 1. kolovoza 1503. ostavlja mnogim svećenicima ponešto neka se mole za njega, a bratovštini svećenika congregationi sive fratalie presbiterorum. Želi da se pokopa u crkvi sv. Lazara izvan Zadra, a glavnim nasljednikom svog imetka imenuje svećenika Bartula, kapelana sv. Lazara. ${ }^{29}$ Svećenik Juraj Oplanić spominje bratovštinu svećenika kod Sv. Duha u predgrađu Zadra pod nazivom „kongregacija“. On ostavlja jedan odjevni predmet kongregaciji svećenika glagoljaša u crkvi sv. Lazara pokraj Zadra. ${ }^{30}$

Na kopnu su djelovale sljedeće svećeničke bratovštine: ${ }^{31}$

- "Bratovština sv. Duha Ravnih Kotara" u koju su se učlanjivali svećenici s kopnenog dijela zadarskog područja, ali i otočki svećenici koji su neko vrijeme djelovali u mjestima zadarskog zaleđa te su i nakon odlaska iz njih ostajali članovi tih bratovština. Sačuvane su dvije madrikule 1691. $-1850 .{ }^{32}$

26 Dijelom sačuvana evidencija. V. Cvitanović, Bratovštine grada Zadra, 468; Vodič arbiva Zadarske nadbiskupije, prir. Oliver Modrić i Josip Kolanović, Zadar, 2013., 59 - 61; HR-AZDN-12, Zadruga bratske pripomoći.

27 V. Cvitanović, Bratovštine grada Zadra, 467; G. Franov-Žıv Ković, Zapisi iz knjige Bratovštine Gospe od Sniga u Sv. Donatu, 18.

28 Na zadarskom području postoji još jedna bratovština sv. Karla Boromejskog u Salima. Bila je svećenička.

29 P. RUnJE, Glagoljica u zadarskoj nadbiskupiji u srednjem vijeku, 202.

30 P. Runje, Glagoljica u zadarskoj nadbiskupiji u srednjem vijeku, 204.

31 Detaljnije o kopnenim svećeničkim bratovštinama vidi u člancima G. Franov-Žıvković, Biogradska glagoljska madrikula Bratovštine od Uznesenja Blažene Djevice Marije 1720. - 1841., u: Biogradska glagoljska madrikula Bratovštine Uznesenja Blažene Djevice Marije 1720. - 1841., Zadar, 2012., ur. Pavao Kero, VII - XV; Bratovštine Ninske biskupije, Znanstveni skup Ecclesia Nonensis: prošlost Ninske biskupije, Nin, 1. - 3. lipnja 2018., (u tisku); Sukošanske bratovštine od 17. do 19. stoljeća, Znanstveni skup Sukošan, rujan 2018., (u tisku).

32 HR-DAZD, Dračevac, Libar od skule Duha Svetoga godišća Gosp. 1691., Per 10/a; P. Kero, Popis glagoljskih kodeksa Zadarske nadbiskupije, drugo izdanje, 34; AZDN, Kožino, Madrikula bratovštine Svetog Duha 1713. - 1818. 
- Biograd, “Bratovština Uznesenja BDM 1720. - 1841.” Sačuvanaje i madrikula. 33

- Sukošan, "Bratovština Gospe od Milosrđa 1728. - 1818."34

Zadarski otoci:

- "Bratovština Večere Gospo(dino)ve" koja je imala sjedište u Ugljanu. Sačuvana je madrikula ove bratovštine iz razdoblja od 1617. do 1816., a madrikula joj je pronađena u Archivio Diplomatico della Biblioteca Civica u Trstu. ${ }^{35}$

- "Bratovština sv. Mihovila (Arhančela)" koja je vjerojatno djelovala na Ižu. ${ }^{36}$ Evidencija joj nije sačuvana. Spomen na ovu bratovštinu nalazimo u oporukama svećenika članova bratovštine. Svećenici s jugoistočnog dijela otoka Ugljana iz Kali i Kukljice učlanjivali su se u Bratovštinu sv. Mihovila na Ižu. Tako u svojoj oporuci don Bože Blaslov iz Kali spominje svoju subraću, redovnike Skule sv. Mihovila Arhanđela. ${ }^{37}$

33 Zavičajni muzej Biograd na Moru, Madrikula Bratovštine Uznesenja Blažene Djevice Marije u Biogradu 1720. - 1841.; Analiza i transliteracija madrikule objavljena u knjizi Pavao Kero, Grozdana Franov-Živković, Milan Perović, Biogradska glagoljska madrikula Bratovštine Uznesenja Blažene Djevice Marije 1720. - 1841., Zadar, 2012.

34 Madrikula je analizirana u: Arturo Cronia, Libar skule B. D. Marije od Milosrđa u Sukošanu kraj Zadra (1727), Prilozi za književnost, jezik, istoriju i folklor, knj. XVI, sv. 1, Beograd, 1936., 29 - 38.

35 Glagoljska madrikula Svećeničke bratovštine zadarskih otoka Večere gospodnje. Registro della confraternita „Coena domini“ dell' isola di Ugliano anno 1617., pronađena je nedavno zahvaljujući gospodinu Marku Šari iz Trsta u Archivio Diplomatico della Biblioteca Civica di Trieste. (sign. R. P. MS 2-2). Prvih 26 folija obilježeno je glagoljskim brojkama, do kraja madrikule stranice nisu paginirane. Nedostaju folije od 9 do 17 . Kapituli se nalaze od folije $1 \mathrm{r}$ do $8 \mathrm{r}$, a popis braće od $18 \mathrm{r}$ do $26 \mathrm{v}$.

36 AZDN, Fond Cvitanović, neobjavljeno. Cvitanović je prilikom obrađivanja svećeničke bratovštine sv. Duha Ravnih kotara (odnosno jedne od madrikula ove bratovštine koja se čuvala u Kožinu) nabrojio nekoliko svećeničkih bratovština zadarskog područja (ne i zadarske, koje je obradio u drugom članku). Među ostalim navodi ovo: „Ova je skula - rekao bih - svećenika, jer je bilo samo 37 sekularaca (1764.-1815) u njoj. Svećeničke bratovštine su postojale: 1) «Coena Domini» od g. 1617. do 1817. u Ugljanu sa 12, kasnije 33 brata. Ali se nije ništa od nje sačuvalo. (Bianchi, II, 93). 2) «Skula od Milosrđa» od g. 1693. do 1830. za područje Sali - Luka. Imala je 172 bratima (Original kod D. A. Strgačića u Salima). I ovdje je kančelir starješina. 3) «Skula B. D. M. od Milosrđa» od 1727. do 1818 u Šukošanu (za cijelu okolicu i donekle otok Pašman). Imala je 52 svećenika i 95 svjetovnjaka. (Glagol.). Izdao ju je Arturo Cronia, Srpska akademija, knjiga XVI. sv. 2. (Prilozi za književnost, jezik, istoriju i folklor), Beograd 1936.9. 4) «Sv. Mihovila» u V. Ižu od oko g. 1740. do 1809. za područje: Kali, Kukljica i oba Iža. (Madrikula se nije sačuvala).“

37 HR-DAZD-20, kut. VII br. 34, 35: „Ostavlan da mi se jima davati vazda na moi god jedna misa kantana i da mi čine reći mis 100 za moju dušu posli moie smarti i da budu rečene u carkvi S(vetoga) Lovrinca u ovomu mistu i da mi jimaju učiniti moi priličan sprovod i da jimaju primiti na moi greb redovnici skule S(vetoga) Mihovila Arhančela i da jim jimaju učiniti kako e priličan." Cijela oporuka objavljena u G. FRANOV-ŽIVković, O kaljskim običajima u razdoblju od 15. do kraja 19 st., Zbornik Kali, ur. Josip Faričić, Zadar, 2017., 237 - 274; O ovoj i ostalim bratovštinama Dugog otoka u pripremi je članak Bratovštine Dugog otoka. 
- "Bratovština sv. Karla Boromejskog", Sali. Sačuvana je madrikula iz razdoblja od 1640. do $1814 .^{38}$

- "Bratovština milosrđa" za sela Sali, Zaglav, Žman i Luku. Sačuvana je madrikula iz razdoblja 1693. - 1828. ${ }^{39}$

- Moguće da je "Bratovština Sv. Duha od Pašmana" bila svećenička jer je kao takvu spominje don Martin Draškić u svojoj oporuci. Po njemu vidimo da su svećenici u isto vrijeme bili članovi i po nekoliko svećeničkih bratovština. Don Martin u isto je vrijeme bio član svećeničke Bratovštine sv. Duha u Pašmanu i BDM u Biogradu. ${ }^{40} \mathrm{Za}$ ovu Bratovštinu Sv. Duha od Pašmana nije sačuvana madrikula.

- Olipska svećenička bratovština "Sv. Petra i Pavla".41

- Bianchi spominje i "Bratovštinu sv. Pavla” koja je postojala od 1695. do 1808. godine na otočiću Galevcu (Školjiću) ispred Preka. ${ }^{42}$

38 Pavao Kero, Popis glagoljskih kodeksa Zadarske nadbiskupije, drugo izdanje, Zadar, 2015., 76 i 77. AZDN, Glagoljska madrikula laičko-svećeničke Bratovštine sv. Karla Boromejskog 1640. - 1814.

39 P. Kero, Popis glagoljskih kodeksa Zadarske nadbiskupije, 79; Libar Bratovštine milosrda nalazi se u Državnom arhivu u Zadru, u fondu Strgačić.

40 DAZD, Fond oporuke iz kancelarije zadarskih knezova, knjiga II, br.335 / Oporuka don Martina Draškića paroka iz Vrane, 27. 1. 1737. Oporuka je već objavljena u članku G. FrANov-Žıvкović, Prezimena mjesta Pakoštane u 17. i 18. stoljeću na temelju glagoljske knjige duša, Radovi Zavoda za povijesne znanosti HAZU u Zadru, 55, Zagreb-Zadar, 2013., 59 - 92. Oporuka glasi ovako: „U ime Boga i Divice Marie amen / 1737 na 27 jenara u Vrani / Ja don Martin Draškić sin pokonoga Ante Draškića nahodeći se parok od Vrane sada nadoeći se u nemoći od moga života a u dobroi pameti od moga razuma odlučuem činiti ovi teštamenat koi oću da ima moć i kripost koliko da bi bia učinen po rukah puplika nodara zadarskoga / ... / Sada budući u skuli s(vetoga) Duha od Pašmana poštovanih redovnikov od koi sam bia priat za brata - narečuem momu bratu da na momu sprovodu bude učinen obid poš(tova)noi braći redovnikom iste skule takoer i skule Blažene $\mathrm{D}$ (jevice) $\mathrm{M}$ (arije) od Uznesena istoi poštovanoi braći / Jisto narećuem da ima biti moi trideseti na vrime koe su bili kuntentati poš(tova)ne skule za doći na moe pohoćenee greba da ima moi brat učiniti obid rečenim skulam i da ima dati poš(tova)nim redovnikom skule $\mathrm{D}$ (uha) $\mathrm{S}$ (vetoga) tri celini priporučuaći se njiovim svetim molitvami / A skuli B(la)žene Gospe od Uznesena braći na dar jedan fillip / ... / Bi svidok na ovomu teštamentu Martin Oparić iz Vrane / Pisah ja don Mikula Ljubanović parok Pakoštani budući molen."Više o ovoj bratovštini vidi u članku Bratovštine otoka Pašmana i njihova glagoljska evidencija, za zbornik s međunarodnog znanstvenog skupa Fenomen glagoljice (u tisku).

41 Sačuvane su dvije madrikule ove bratovštine AZDN, Glagoljska madrikula Bratovštine sv. Petra i Pavla, 1727. i Glagoljska madrikula Bratovśtine sv. Petra i Pavla 1729. - 1822.; P. Kero, Popis glagoljskih kodeksa Zadarske nadbiskupije, Zadar, 2015., 51, 52.; Carlo F. BIANCHI, Kršćanski Zadar, II dio, Zadar, 2011, 47: „Bratovština svetih apostola Petra i Pavla, sastavljena od svećenika i laika. Potvrdio ju je nadbiskup Zmajević 1719. zajedno s njezinim statutima koje je popravio 1773. nadbiskup Triali na nagovor članova bratovštine. Njih je 1808. bilo 25 , a danas ih je samo šest. Nemaju ni prihode ni vlastite oltare. Zadaća im je bila da slave nekoliko misa za smrt svojih članova.“

42 C. F. BiAnchi, Kršćanski Zadar, II dio, 103: „Stara bratovština pod nazivom Škola sv. Pavla postojala je u ovoj crkvi od 1695., ali je 1808. ukinuta.“ 


\section{OTOČKE BRATOVŠTINE SVEĆENIKA}

Otočke bratovštine svećenika nalazimo još u srednjem vijeku. U oporuci od 14. 7. 1501. koju je u Zadru pisao svećenik Franjo Skarabelić, župnik crkve sv. Nikole u Božavi, ostavlja svojoj crkvi šest zlatnih dukata, jedan dukat crkvi sv. Stošije u Zadru u kojoj želi da ga pokopaju, po jedan dukat ostavlja i crkvama sv. Jakova u Solinama i sv. Leonarda u Dragovama, a bratovštini svećenika glagoljaša, kojih je dvanaest, ostavlja jednu kapsu punu stvari neka to podijele izmedu sebe. Novca nema jer je potrošio na liječenje. Izvršitelji (komesari) oporuke neka prodaju njegov brevijar i neka novac podijele sirotinji. ${ }^{43}$ Već su gore spomenuti stric i nećak Šimun Mirojević (Mirojić) i Grgo Mirojević (Mirojić), sin Pavla, koji su bili bratimi dviju svećeničkih bratovština i zadarskih otoka i zadarske Bratovštine sv. Stjepana. ${ }^{44}$

Otočki svećenici bili su članovi i laičkih bratovština, pa tako iz jedne oporuke saznajemo da je Toman Matešić Mavrović bio predstavnik otočkih svećenika. ${ }^{45}$

\section{MADRIKULA SVEĆENIČKE BRATOVŠTINE ZADARSKIH OTOKA VEČERE GOSPODNJE ${ }^{46}$}

Ovo je bratovština svećenika ${ }^{47}$ sa sjeverozapadnog dijela otoka Ugljana te dijelom otoka Iža, Sestrunja, Oliba, Molata, Vira, Silbe i dijelom svećenika sa sjeverozapadnog dijela Dugog otoka, nekoliko osoba s kopnenog dijela

43 Nije naveden naziv svećeničke bratovštine. (P. Runje, Glagoljica u zadarskoj nadbiskupiji u srednjem vijeku, 201, 203, 204).

44 P. Runje, Glagoljica u zadarskoj nadbiskupiji u srednjem vijeku, 202, 203.

45 P. Runje, Glagoljica u zadarskoj nadbiskupiji u srednjem vijeku, 202, 203. Toman Matešić u svojoj glagoljskoj oporuci od 22. lipnja 1466. ne spominje bratovštinu otočkih svećenika. Acta Croatica = Listine hrvatske, prir. Ivan Kukuljević Sakcinski, Zagreb, 1863.; Novije izdanje: Acta Croatica, Hrvatski spomenici. Hrvatske glagoljične i ćirilične isprave iz zbirke Stjepana Ivšića 1100. - 1527., Knjiga I, prir. Josip Bratulić, Zagreb, 2017., 185, br. 77.

46 Archivio Diplomatico della Biblioteca Civica di Trieste (dalje: ADBCT), Madrikula Svećeničke bratovštine zadarskih otoka Večere gospodnje. Registro della confraternita "Coena domini“ dell” isola di Ugliano anno 1617., sign. R. P. MS 2-2.

47 C. F. BIANCHI, Kršćanski Zadar, II. dio, 88, 89. Bianchi ovu svećeničku bratovštinu naziva Vjerska družba zadarskih otoka nazvana Coena Domini: „Ranije je na zadarskim otocima djelovala družba hrvatskih svećenika pod nazivom Coena Domini (Večera Gospodnja, op. pr.). Bila je ustanovljena u selu Ugljanu u crkvi sv. Marije 27. studenog 1617. Sastojala se od 12 svećenika u sjećanje na zbor apostola, a kasnije se broj povećao na 33, u spomen na godine života Spasitelja Isusa Krista. Glavna zadaća te družbe bila je u tome da na poseban način slavi sv. sakramenat euharistije, da se zauzima za svoju mrtvu subraću, molitvom i žrtvama, te da čini druga pobožna djela radi postizanja oprosta grijeha, koje je takvim društva udjeljivao Urban VIII. Imali su konstitucije koje je već u početku 
Zadarske nadbiskupije te dva zadarska nadbiskupa i jednog skradinskog biskupa te manjeg dijela svjetovne braće uglavnom iz plemićkih obitelji, nešto obrtnika, brodovlasnika (paruna) i kapetana teritorijalnih snaga. ${ }^{48} \mathrm{Ne}$ nalazimo svećenike s jugoistočnog dijela Dugog otoka i ni jednog s otoka Pašmana i Vrgade, koji su bili učlanjeni u druge svećeničke bratovštine. Kopneni dio pokrivale su bratovštine Duha svetog Ravnih kotara, sukošanska Gospa od Milosrđa te biogradska Bratovština od Uznesenja BDM, u njihovim madrikulama $\mathrm{u}$ popisima bratima nalazimo ove iste svećenike s Ugljana koji su neko vrijeme radili na kopnu. U saljskim bratovštinama sv. Karla Boromejskog i Gospe od Milosrđa nalazimo svećenike s područja Sali i jugoistočnog dijela Dugog otoka, a u olipskoj madrikuli sv. Petra i Pavla svećenike iz Oliba i nešto svećenika sa sjeverozapadnog dijela zadarskog otočja. Na Ižu je djelovala Bratovština sv. Mihovila u koju su se učlanjivali bratimi jugoistočnog dijela otoka Ugljana i Iža. U madrikuli Večere gospodnje ne nalazimo upisane sve svećenike sa sjeverozapadnog dijela otoka Ugljana, već samo one koji su dobili dozvolu upisa u bratovštinu, dakle elitni dio svećenika. ${ }^{49}$ Prema tome, ne začuđuje što se među članovima nalaze osobe za čije zbornike tekstova i druge rukopise znamo i danas, kao što su: don Ive Grdović rečeni Ivanov, ${ }^{50}$ don Ive Čubanov

odobrio nadbiskup Garzadori, zatim ih je potvrdio i nadbiskup Zmajević 1743., te generalni providur Francesco Dalier 1784. U konstitucijama postoji članak koji nalaže članovima bratovštine da se svake godine upute u Zadar, u prvostolnicu, te da pjevaju svečane mise tijekom osmodnevne svetkovine Corpus Domini (Tijelovo) na oltaru sv. Sakramenta, za napredak Mletačke Republike i u duždevo zdravlje.“

48 I u drugim svećeničkim bratovštinama primaju svjetovnjake, npr. Zavičajni muzej Biograd na Moru, Madrikula Bratovštine Uznesenja Blažene Djevice Marije u Biogradu 1720. - 1841.; AZDN, Glagoljska madrikula Bratovštine sv. Petra i Pavla, 1727. i Glagoljska madrikula Bratovštine sv. Petra i Pavla 1729. - 1822. U kapitulu 7 piše da primaju nekoliko svjetovnih ljudi; AZDN, Glagoljska madrikula laičko-svećeničke Bratovštine sv. Karla Boromejskog 1640. - 1814. U kapitulu 10 određeno je da se ne primi više od 4 mundanib; HR-DAZD, Dračevac, Libar od skule Duha Svetoga godišća Gosp. 1691., Per 10/a: „Obyliubismo mi brachia od skule redovnici, da primemo svitovna bratta çetiri u skulu; a tolikoyer su poglaviti i dobri, veche nikad vise."

49 Zavičajni muzej Biograd na Moru, Madrikula Bratovštine Uznesenja Blažene Djevice Marije u Biogradu 1720. - 1841.; Analiza i transliteracija madrikule objavljena u knjizi Pavao Kero, Grozdana Franov-Žıvković, Milan Perović, Biogradska glagoljska madrikula Bratovštine Uznesenja Blažene Djevice Marije 1720. - 1841., Zadar, 2012.; U biogradskoj madrikuli nalazimo listu počeka, tj. listu čekanja prijavljenih kandidata (prokura) za ulazak u bratovštinu, i redovnika (fol. 78v) i šekulara (fol. 87v), a uz prijavu su kandidatima bile nužne preporuke starih članova bratovštine; P. Kero, Popis glagoljskih kodeksa Zadarske nadbiskupije, drugo izdanje, 17.

so Ne može se još točno odrediti tko je napisao ovaj zbornik jer u izvorima nalazimo dvije osobe $s$ istim imenom don Ive Grdović rečeni Ivanov, jer matice za župu Sutomišćica nisu sačuvane, a nedostaje dobar dio knjige godova; Arhiv HAZU, Grdovićev zbornik, 18. st., sign. I d 40 (Kuk 748); V. ŠTEFANIĆ, Glagoljski rukopisi Jugoslavenske akademije II, Zagreb, 1970., 69 - 76; P. Kero, Popis glagoljskih kodeksa Zadarske nadbiskupije, drugo izdanje, 103. 
rečeni Vlahić, ${ }^{51}$ don Jure Čubanov (Vlahić), ${ }^{52}$ don Jerolim Kuzmić Šimić, ${ }^{53}$ don Mikula (Nikola) Belić, ${ }^{54}$ don Miho Vukojević rečeni Milin ${ }^{55}$ itd., a među samim osnivačima bio je i don Mikula Fatević, pisar Fatevićeva zbornika duhovnog štiva. ${ }^{56}$ Možemo pretpostaviti da su i ostali bratimi ove bratovštine po uzoru na svoju subraću zapisivali svoje propovijedi i zbornike tekstova, ${ }^{57}$ ali da nisu sačuvani.

Bratovština Večere Gospodinove osnovana je 27. studenog 1617. godine u crkvi svete Marije u mjestu Ugljan na otoku Ugljanu. Tom prilikom osnivači su izglasali 27 kapitula, nakon toga su prilikom skupa u svetoj Eufemiji (Fumi) u Sutomišćici (nema datuma) izglasali kapitul 28. Godine 1747. na godišnjem skupu izglasan je kapitul 29, a u crkvi svete Fumije (Fume) 1750. i 1803. godine kapituli 30 i 31. Popis osnivača donosim u daljnjem tekstu, a kapituli su doneseni u Prilogu.

U prvom kapitulu odredili su da bratovština ima samo tridesetoro braće, a kad bi koji brat umro ili otišao (dobrovoljno ili bio istjeran zbog nepridržavanja pravila), na njegovo je mjesto mogao biti izabran drugi brat. U kasnijem kapitulu br. 17 dopisano je da se braća mogu dogovoriti za veći broj braće od 30, a u kapitulu 24 dopisano je da se bira 33 brata. Izbor se pravi balotavanjem ili glasovanjem.

Kapitul 3 propisuje da bude izabran (balotanjem) jedan sudac (starešina) bratovštine, a u kasnijem tekstu kod zapisnika s redovnih godišnjih skupština vidimo da je sudac (nazivan vikarij ili digan) sam birao jednog ili dva brata za svoje pomoćnike (prokarature) te jednog zapisničara odnosno tajnika (kančilira). ${ }^{58}$

51 Grozdana Franov-ŽIv ković, Glagoljaš don Ive Vlahić (Sutomišćica, oko 1733. - 25.07.1803.), Radovi Zavoda za povijesne znanosti HAZU u Zadru, 54, Zagreb-Zadar, 2012., 147 - 183; G. Franov-Žıv Ković, Bratovštine (skule) župe sv. Eufemije (Fume) u Sutomišćici na Otoku Ugljanu u 18. st., 165 - 227; G. Franov-Žıvković, Bratovštine (skule) župe Blažene Gospe od Luzarija u Preku na otoku Ugljanu u 18. st. i 19. st., 231 - 259.

52 Grozdana Franov-Žıvković, Don Jure Čubanov (Sutomišćica, oko 1754. - Lukoran, 22. 10. 1830.). Zbornik sa znanstvenog kolokvija: Svećenici glagoljaši i njihova ostavština, Zadar (u tisku).

53 Grozdana Franov-Žıvković, Život i djelo glagoljaša don Jerolima Kuzmića Šimića (župa Sutomišćica, oko 1726. - 4.12.1793.), Croatica Christiana Periodica, 75, godina XXXIX, Zagreb, 2015., 89 - 102.

54 P. Kero, Popis glagoljskih kodeksa Zadarske nadbiskupije, 115, 116.

55 DAST, arhiv obitelji Fanfogna-Garagnin, glagolitika, Iz katehizma Mihe Vukojevića rećenoga Milina iz Ugljana, 18. st.; P. Kero, Popis glagoljskih kodeksa, 2. izdanje, 117.

56 P. Kero, Popis glagoljskih kodeksa Zadarske nadbiskupije, drugo izdanje, 74; Članak o don Mikuli Fateviću i Zborniku tekstova, kao i cijelu transliteraciju zbornika vidi u knjizi Grozdana FranovŽıv Ković, Fatevićev zbornik duhovnog štiva, 1617., Riznica glagoljaške kulture i hrvatske pismenosti otoka Rave, niz Monumenta glagolitica Archidioecesis Iadertianae, ur. Pavao Kero, Blaga Bunčuga i Josip Faričić, Zadar. 2016.

57 Tekstove su sami zapisivali, ili prepisivali od drugih, ili kompilirali.

58 Sličan izbor kod kojeg glavni sudac sam izabire svoje pomoćnike nalazimo u bratovštini sv. Mihovila u Vrsima. AZDN, Glagoljska madrikula Bratovśtine sv. Mihovila 1700. - 1822. 
Kapitulom se određuje da glavni sudac mora izvršavati svoje obveze, a bratimi moraju poštovati njegove naredbe te je za sve propisana kazna u slučaju kršenja odredbi. Kazne su propisane i za kršenje moralnih odredbi kao što su psovanje, napadanje na drugu braću ili klevetanje (kapituli 4 i 22). ${ }^{59} \mathrm{U}$ slučaju balotavanja ili glasovanja starešina (glavni sudac - vikarij) može dati dva glasa ili balote (kapitul 18). Po kapitulu (članku) 20 Sud časti sačinjava glavni sudac (vikarij) te četiri najstarija brata u bratovštini (ako bi se pohodilo ko prigovaranje ili pravda). Kazne su bile novčane ili u težim slučajevima i izbacivanje iz bratovštine (kapitul 22).

Godišnje skupštine održavale su se treću srijedu po Vazmu, i to kod brata koji bude određen, a ako koji od određene braće ne organizira brašćinu, platit će kaznu od jednog dukata. Ostala braća moraju novčano pomagati ili sudjelovati u organiziranju skupa. Po zapisnicima je vidljivo da se nisu držali odredbe da se skup održava u srijedu, već se uglavnom održavao utorkom. Na skupštinama sudjeluju samo redovnici, ne i svjetovna braća, koja su također primana u bratovštinu (kapitul 21).

Ako je neki brat upao u nevolju, ne svojom krivnjom, ostala braća moraju mu priskočiti u pomoć bilo financijski, bilo kao moralna podrška (kapitul 7). Posebno poštovanje imaju starija braća, koju mlađa u svakom trenutku moraju poštovati (kapitul 8). Za mrtvu braću govori se deset svetih misa (kapitul 9), da novac za pogreb (kapitul 28) te obavezno prisustvuje pogrebu (kapitul 10,27), a mise se govore za sve duše od purgatorija (kapitul 12) te protiv hereze i poluvjerstva, kao i za opstojnost Mletačke Republike te zadarskog nadbiskupa i drugih osoba pri vlasti, zatim protiv kuge, nagle smrti, tuče i svakoga zla (kapitul 13). Da bi se izbjegla protekcija prilikom primanja u bratovštinu bratimi su izglasali kapitul 11 po kojem se ni jedan brat ne može primiti u bratovštinu bez izglasavanja dvotrećinske većine braće. Svaki dobrovoljni izlazak iz bratovštine kažnjava se jednim dukatom (kapitul 14). ${ }^{60}$ Po kapitulu 15 novčane kazne skuplja sam vikarij (glavni sudac), koji novac ne ostavlja bratovštini, već daje siromašnima (ubozim). Braća moraju biti solidarna, pa tako ne mogu u skulu primati žakna koji je otišao od nekog drugog od braće (kapitul 16). Ako bi koji bratim otišao iz svog mjesta na duži rok od pet godina, bit će izbačen iz bratovštine (prekrižen od braće), a ako

59 Sve bratovštine imaju kazne za nemoralno ponašanje i nepridržavanje pravila. Npr. HR-DAZD, Dračevac, Libar od skule Duha Svetoga godišća Gosp. 1691., Per 10/a, kapitul 7: „Koyi bi brat na brata krivo svidočijo koyu stvar da je kastigan lib(ar) 30; kapitul 4: Ako bi brata udario da je kastigan li(bar) 40 i da ga bracha izvargu od brastine kako nevirnika i odmetnika boxyega"; AZDN, Glagoljska madrikula laičko-svećeničke Bratovštine sv. Karla Boromejskog 1640. - 1814., kapitul 10: kažnjen bi bio onaj brat koji bi napravio ki kustion.

60 HR-DAZD, Dračevac, Libar od skule Duha Svetoga godišća Gosp. 1691., Per 10/a. U bratovštini Svetog Duha Ravnih kotara kazna za izlazak iz skule bila je 60 libara (kapituli pisani 1691. godine). 
bude odsutan kraće vrijeme, njegove obveze treba preuzeti drugi bratim kojeg dotični sam predloži, odnosno imenuje (kapitul 17). ${ }^{61}$ Bratovština se kapitulom 23 ograđivala od bratima koji su optuženi za silovanje ili izvanbračni život ( $k o i$ pribiva u nečistoći) jer za svećenike nije bio nadležan civilni sud (zato ovakvu odredbu nemaju laičke bratovštine), već vjerski, tj. nadbiskup, a bratimi odlučuju da ga istjeraju iz bratovštine. ${ }^{62}$ Po kapitulu 25 , u slučaju ako bratim nešto sagriješi i ne želi se podložiti Sudu časti, mora otići na odgovornost nadbiskupu ili nekom njegovu opunomoćeniku (namisniku). Braća određuju hodočašće svake godine u Zadar u katedralu svete Stošije gdje će s dozvolom nadbiskupa govoriti svete mise (kapitul 26), a ujedno se svake godine planiralo hodočašće u Asiz gdje su se govorile mise za umrlu braću. Novac su skupljala sva braća i određivan je jedan od njih koji je išao na putovanje u Asiz. U slučaju da nije mogao jedan od bratima, vikarij je bio dužan pronaći zamjenu u jednom od braće koja nisu članovi bratovštine (kapitul 28).

Zanimljiv je kapitul 29 izglasan 1747. godine koji se odnosi na štednju jer su te godine bile oskudne i nije se moglo dopustiti preveliko trošenje, posebno ne uvozne spize (jizbine i vina od dalečnih mistov, a to mustardu, sir pijažentin, konfeturli nijedne vrste, kolačići, grozja muškat, ni vina frustirska, pošade srebarne) i dohoditi ćiniti robu od mistov odalečnih i broditi srebro priko mora s velikim rizikom. Ovih su godina harale bolesti i glad, ${ }^{63}$ a vladala je stalna opasnost na kopnu i moru od napada razbojničkih bandi i gusara. ${ }^{64}$ Prokaraturu

${ }_{61}$ U madrikuli postoji jedan ovakav primjer koji vidi u daljnjem tekstu.

62 Grozdana Franov-ŽIv ković, Glagoljske moralno-kazuističke odredbe ninskih biskupa 17. i 18. st., Radovi Zavoda za povijesne znanosti Hrvatske akademije znanosti i umjetnosti u Zadru, 57. Zagreb-Zadar, 2015., 185 - 216; Sličnu odredbu nalazimo u svećeničkoj bratovštini Svetoga Duha Ravnih kotara, kapitul 7: „I koyi bi bio bludnik oçiti, da ga imaju bracha odvarchi od sebe; Za koyin bi bio za(o) glas da ga mogu brachia oçito pokarati meu sobon.“ (HR-DAZD, Dračevac, Libar od skule Duha Svetoga godiš́a Gosp. 1691., Per 10/a); O nadležnosti vjerskih i civilnih sudova za kaznena djela svećenika vidi u: Fabiana Veronese, Terra di nessuno. Misto foro e conflitti tra Inquisizione e magistrature secolari nella Repubblica di Venezia (XVIII sec.), doktorski rad, Venecija, 2010. (dspace.unive.it $>$ handle >, posjećeno 17. 2. 2020.)

63 Šime Peričić, Gospodarska povijest Dalmacije od 18. do 20. stoljeća, Zadar, 1998., 13.

64 Miroslav BertošA, Zlikovci i prognanici, Pula, 1989. Bertoša opisuje pojavu razbojništva na području Istre; M. BERTošA, Izazovi povijesnog zanata, Lokalna povijest i sveopći modeli, Zagreb, 2002.; Razbojništvo nije bilo samo lokalna pojava, već je u ovo vrijeme bilo često po cijeloj Europi. $\mathrm{Na}$ zadarskom se području također bilježe pojave razbojničkih bandi, npr. Sukošanske matične knjige (HR-DAZD, Sukošan, Glagoljska matica umrlih 1658. - 1759.; Sukošan, Glagoljska matica umrlih 1765. - 1799.; Sukošan, Latinička matica umrlih 1800. - 1826.; Državni arhiv u Splitu (DAST), Fond Fanfogna-Garagnin, glagolitica, Sukošan, Glagoljska matica umrlih 1608. - 1658.); I na području Starigrada također se bilježe problemi s razbojnicima. U maticama Tribnja i Selina u pojedinim je upisima naznačeno da su ljude ubili loši momci, neprijatelji ili hajduci (G. Franov- 
se nalaže da kupi 33 pošade s novcem od skule. U kapitulu 30 određuje se 1750. godine velika štednja (draginja) od svih stvarih pa se zato na bratskom stolu (objed prilikom godišnje skupštine) određuje sljedeća hrana: kruh, vino, manestra, kokoške, tripe, štud (kratica za nešto), meso kuhano i pečeno te sir samo jedne vrste.

Iz kapitula ove i svih svećeničkih bratovština vidljivo je da naglasak stavljaju na duhovnu komponentu (molitva za živu i mrtvu braću, prisustvovanje pogrebima, naglasak na moralu članova) te humanitarnu jer dohodak od kazni i ostalo ne zadržavaju za sebe, već daju siromašnima, pa čak i kad su mlađa braća počela pretjerano trošiti, to su zaustavili kapitulom 29 te kapitulom 30 i stavili naglasak na skromniju spizu. U svećeničkim bratovštinama ne nalazimo ulogu bratovština kao ekonomskih zadruga, komunalnih poduzeća ili financijskih zadruga (posuđivanje novca) jer im primarna uloga nije bilo poboljšanje ekonomskog položaja svećenika. Pretpostavljali su da bratimi svećenici imaju dovoljno sredstava za život (patrimoniji), a svjetovna braća upisana u bratovštinu bili su posjednici, brodovlasnici (paruni), obrtnici itd. koji su imali dovoljno sredstava za život, a često bili i dobročinci koji su ostavljali veća sredstva bratovštini.

Iza kapitula nalazimo popis članova skule:

1617 godine ovdi se pišu gos(po)da redovnici brati skule Bule Večere Isukrstove

Zapisivano je različitim rukopisima pa možemo pretpostaviti da su prvim rukopisom kojim su pisana i pravila (kapituli) na dvije stranice popisana dvadesetorica bratima osnivača bratovštine. Kančiliri su pored imena i prezimena nekih bratima pisali njihov datum smrti.

$\mathrm{Na}$ te dvije prve stranice nalazimo sljedeće svećenike:

1. Poś(tova)ni brat don Luka Miroić iz Uglana (preminuo 1631.)

2. Poš(tova)ni brat don Matii Fatović od Uglana

3. Poš(tova)ni brat don Šimun Vladić od Savra

4. Poš(tova)ni brat don Mate Pribić iz Uglana

Žıvnović, Mate Bobanović, Povijesna demografija Starigrada na temelju matičnih knjiga iz 19. stoljeća i glagoljskih i ostalih dokumenata nastalih u razdoblju od kraja 17. do sredine 19. stoljeća, Zbornik sa Znanstveno-stručnog skupa Starigrad-Paklenica (u tisku); G. Franov-Žıv Ković, M. BobANović, Povijesna demografija Selina na temelju matičnih knjiga iz 19. stoljeća i glagoljskih i ostalih dokumenata nastalih u razdoblju od kraja 17. do sredine 19. stoljeća, Zbornik sa Znanstvenostručnog skupa Starigrad-Paklenica, (u tisku); G. Franov-Žıvković, M. Bobanović, Povijesna demografija Tribnja na temelju matičnih knjiga iz 19. stoljeća i glagoljskih i ostalih dokumenata nastalih u razdoblju od kraja 17. do sredine 19. stoljeća, Zbornik sa Znanstveno-stručnog skupa Starigrad-Paklenica (u tisku). 
5. Poš(tova)ni brat don Ivan Žentiličić iz Uglana

6. Poš(tova)ni brat don Lovrinac Miro/v/ić iz Uglana

7. Poš(tova)ni brat don Miho Sušić iz Uglana

8. Poš(tova)ni brat don Ivan Vladić iz Uglana

9. Poš(tova)ni brat don Mikula Fatović od Luke

10. Poš(tova)ni brat don Šime Fatović od Jiža

11. Poš(tova)ni brat don Šime Jurišić od Jiža

12. Poš(tova)ni brat don Luka Filipović od Božave

13. Poš(tova)ni brat don Ivan Mandić od Molata

14. Poš(tova)ni brat don Jive Jadrišić od Puntebijanke

15. Poś(tova)ni brat don Matij Herman od Puntebijanke

16. Poš(tova)ni brat don Ivan Vidušević od Puntebijanke

17. Poš(tova)ni brat don Dunat Mičić od Sutumišcice

18. Poš(tova)ni brat don Ivan Vitulić od Silbe

19. Poš(tova)ni brat don Jurai Mičić od Sutumišcice

20. Poš(tova)ni brat don Grgur Mičić od Sutumišćice

Popis se dalje nastavlja drugim rukopisima na sljedećim stranicama madrikule, a obuhvaća folije od 18 do 26.

Među kasnije dopisanim članovima nalazimo i zadarske nadbiskupe Vicka Zmajevića od Kotora, Perasta ${ }^{65}$ i Ivana Karšanu ${ }^{66}$ te skradinskog biskupa Civalelića iz $\mathrm{Grada},{ }^{67}$ kao i cijeli niz poznatih svećenika, župnika župa otoka Ugljana, Iža,

65 Nije naveden datum upisa u bratovštinu. P. KERo, Leksikon svećenika Zadarske nadbiskupije (u rukopisu): „Zmajević, Vicko, nadbiskup, rođen 23. prosinca 1670. godine u Perastu u Boki Kotorskoj. Bogoslovne nauke završio je u Rimu. U 30. godini 1700. postaje Barski nadbiskup. Sveta Stolica ga imenuje 22. svibnja 1713. zadarskim nadbiskupom. Punih 32. godine je upravljao biskupijom do svoje smrti koja je nastupila 11. rujna 1745. Pokopan je u crkvi Gospe od zdravlja u Zadru. Ima velike zasluge za narod osobito za hrvatski puk jer je utemeljio glagoljaško sjemenište za odgoj klera koje traje do danas. Zatim poznat je po tome što je u pregrađe Zadra doveo nekoliko obitelji albanskih obitelji gdje osnivaju župu i selo Arbanasi. (Usp. Carlo F. Bianchi, Zara Cristiana I. Zadar, 1877. str. 71-73; Vinko Kraljević, Gli ortodossi negli scritti di Vincenzo Zmajević, Roma, 1996).“

66 Upisan u bratovštinu 23. srpnja 1786. Zapis je na talijanskom i hrvatskom jeziku i latinici. P. Kero, Leksikon svećenika Zadarske nadbiskupije (u rukopisu): „Karsana, Giovanni, potječe iz glasovite obitelji iz Zadra, gdje je rođen dana 7. studenoga 1718. Kao mlad prigrlio je crkvenu službu; prvo obrazovanje stekao je u sjemeništu Florio u Zadru, a zatim je pohađao studij filozofije i teologije u samostanima. Kad se zaredio, predavao je filozofiju u gore spomenutom sjemeništu te u sjemeništu u Splitu; i u jednom i u drugom obavljao je i funkciju rektora. Zatim je otišao u Padovu, odakle se, nakon što je dobio stupanj doktora svete teologije, vratio u zavičaj, Zadarski nadbiskup 1774.“

67 Vicko Kapetanović, Skradinski biskupi i građevine u porječju Krke u 18. stoljeću prema arhivskim spisima, Titius, god 1, br. 1, 2008., 37: „Koristeći se pravom imenovanja biskupa, Senat 
Sestrunja, Oliba, Molata, Silbe i dijelom svećenika sa sjeverozapadnog dijela Dugog otoka.

A na kraju popisa braće slijedi tekst na latinici o skupu skule koji je održan 1816. godine u Samostanu svetog Jerolima u Ugljanu, ${ }^{68}$ na kojem je u bratovštinu

je 7. ožujka 1695. imenovao za skradinskog biskupa zadarskog svećenika Grgura Civalellija, a za makarskog biskupa Nikolu Bijankovića, odredivši im posebnim dekretom po 1000 dukata troškove za uzdražavanje, i zatražio od pape da ih potvrdi. Posebna kongregacija kardinala ispitala je zahtjev i predložila papi Inocentu XII. kandidate s preporukom da Republika pojedinom biskupu osigura 1500 dukata za uzdržavanje, arhiđakonima 200, kanonicima po 100 te 20 za stan i hranu, četvorici prezbitera po 50 dukata i četvorici klerika po 25 dukata, dok traje rat protiv Turaka, a poslije rata toliko zemljišta koliko odgovara navedenoj svoti,15 što je Senat 1697. i prihvatio. Sljedeće godine ustanovljena je dužnost arhiđakona za svaku katedralu, s dvostrukom kanoničkom pristojbom. Nakon što se Venecija obvezala i dodijelila biskupima i kaptolima prihode za uzdržavanje, 11. svibnja 1697. dodijelila im je katedrale i prebivališta. Rim je 19. prosinca 1698. potvrdio Civalelija za skradinskoga biskupa i odredio mu pristojbu u iznosu od 143 i 1/3 florena. Posvećen je za biskupa 24. svibnja 1799. i zaposjeo biskupsku stolicu 18. lipnja 1700., na kojoj je ostao do smrti 1713. Bio je to prvi skradinski biskup koji je svečano ušao u Skradin nakon oslobađanja od Turaka. A Skradinjani su biskupe dočekivali svečano, što se može zaključiti iz opisa svečanog ulaska kasnijega biskupa Pasqualiga, koji je jahao na konju u pratnji do mjesta gdje ga je čekalo biskupsko misno ruho, a odatle je krenuo u povorci pod nebnicom koju su nosili gradski plemići. Putem mu se klicalo i recitiralo pjesme.“

68 Samostan sv. Jerolima u Ugljanu poznat je po grobu obitelji Kožičić Benja. U njoj je pokopan poznati glagoljaš Šimun Kožičić Benja. P. KERo, Leksikon svećenika Zadarske nadbiskupije (u rukopisu): „Kožičić-Benja, Šimun, biskup, rođen u Zadru, 1460. Član je jedne od najstarijih plemićkih obitelji. Umro je u Zadru u ožujku 1536. Pokopan je u crkvi samostana Male braće u Ugljanu, koji je osnovao njegov djed Šimun . Bio je zadarski kanonik, biskup modruški i upravitelj biskupije senjske. Kao visoki crkveni dostojanstvenik osobito se istaknuo po svom domoljubnom djelovanju u teško doba hrvatske povijesti zbog turskih provala u Hrvatsku. Na Lateranskom saboru u svojim govorima 1513. i pred papom Leonom X. (1516.) iznosi teško stanje u Hrvatskoj i traži pomoć u borbi protiv Turaka. Ti su govori kasnije tiskani u Mlecima (1530.) i posvećeni su Bernardinu Frankopanu. Šimun Kožičić Benja posebno je poznat kao utemeljitelj treće po redu glagoljaške tiskare u Hrvatskoj. Tiskara je djelovala u Rijeci 1530. i 1531. i u njoj je biskup Kožičić bio upravitelj, pisac i urednik. Tiskara je tiskala, koliko je danas poznato, šest knjiga glagoljicom na hrvatskoj čakavskoj redakciji starocrkvenoslavenskog jezika: Oficij blažene devi Marije, Misal hrvacki, Knjižice krsta, Knjižice od žitija rimskih arhijerejov i cesarov, Psaltir, Od bitija redovničeskog i, možda, Psaltir. Knjiga Knjižice od žitija rimskih arhijerejov i cesarov zapravo je biografsko-leksikografsko djelo i po tome je jedno od jedinstvenih takvih djela na hrvatskom jeziku iz toga doba. Na koncu toga djela poznata je Kožičićeva posveta slavnom trogirskom biskupu Tomi Nigru, u kojoj ga Kožičić moli da piše o zemlji Hrvatskoj i njezinoj slavi, a to bi onda Kožičić tiskao. Biskup Šimun Kožičić Benja zadužio je hrvatski narod po svom izrazitom domoljublju, brizi i borbi za Hrvatsku u teškim danima njezine povijesti. U hrvatskoj kulturi trajan mu je spomen kao utemeljitelju i voditelju hrvatske glagoljaške tiskare u Rijeci. Šimun Kožičić Benja pripada slavnom nizu hrvatskih biskupa koji su iskreno i predano služili probitcima svoga naroda. (Usp. Carlo F.Bianchi, Zara cristiana, Zara, 1877., vol. I. str. 205-206; Julije Derossi, Perivoj od slave, Zadar, 2002., str. 16).“ 
primljen zadarski arhižakan Ivan Jurović, ${ }^{69}$ bez obveza davanja članarine, ali da bude odvjetnik (zagovornik) bratovštine: ${ }^{70}$

Danas ova s(veta) skulla od Veçere Gospodinove ovdi na Uglianu skuplena u namastiru S(vetoga) Jerolima, sva skupgliena brachia jesu mogla pripostovanoga gospodina gospodina Ivanna Giurovichia nauçiteglia ovih zakonna, arcixakna stolne zadarske zcarkve i/ja d(on) Pave Perić brat scule Veçere Gospoinove redovniku ove s(vete) skule brezi kakove obiçajne duxnosti dalli kao odvitnik iste nasce skule, tako da uxiva i na ovomu i na drugomu s(v)itu sva prostegnia od s(vetoga) otza pape Urbana VIII dopustena na 16. otobra 1816.

Bilo je više kancelara bratovštine koji su vršili upise u madrikulu. Don Ive Vlahić, ${ }^{71}$ koji je svojom rukom u cijelom popisu zapisivao pored imena i prezimena svećenika kad je tko preminuo, vjerojatno je neko vrijeme obnašao dužnost kančilira, što ne vidimo iz tablice jer nedostaje popriličan broj zapisnika $s$ godišnjih skupština što bi ukazivalo na to da ova madrikula ili nije u cijelosti sačuvana, ili da je postojala još koja izgubljena knjiga ove bratovštine. Zapisano je da je bio domaćin brašćine (godišnje skupštine) 1772. godine pa postoji mogućnost da je prethodne godine bio i glavni sudac. Dana 13. svibnja 1772. godine don Ive Vlahić organizira bratski stol te podnosi izvješće o stanju inventara bratovštine koji glasi: 1772 na 13 maja na brašćini g(o)s(po)dina d(on) Ive Vlabića nota od sve robe od skule Večere Isusove / I ova roba bi pridana sva gos(po)dinu d(on) Šimi Šimiću / bi svić zagoreti 51 dunplirov 10 kamiža su 3 paramenat 1 edan crni $i$ strete crne drugi parament šari i štrete $i$ plovial $i$ kesa i faco $i$ prcibul $i$ kadimnik $i$ nav i navižela $i$ žlicica od srebra i prešćene i busul ova roba je sva pridana gos(podi)nu $d($ on) Šimi Šimiću od Sutumišcice.

P. Kero, Leksikon svećenika Zadarske nadbiskupije (u rukopisu): „Đurović (Jurović, Giurovich, Giovanni) Ivan, rođen u Zadru 8. veljače 1752. Studij je završio u Loretu. Kanonik Prvostolnog kaptola sv. Stošije u Zadru, generalni vikar i više godina je upravljao Zadarskom nadbiskupijom. Ravnatelj sjemeništa Florio. Umro 17. siječnja 1828. (Usp. Hrvatski biografski leksikon, VI. str. 657-658; Carlo F. Bianchi, Zara cristiana, Zara, 1877., vol I, str. 228-232). Kao mladić upisao se u crkvene redove; Kaptol ga je poslao u zavod u Loretu, gdje je, završivši sve studije, diplomirao filozofiju i teologiju. Vrativši se u zavičaj, određen je za mansionara zborne crkve sv. Šime, zatim je priključen svećenstvu katedrale, a 1784. imenovan je kanonikom pokorničarom, kasnije arhiprezbiterom i, jednoglasnim izborom od 26. veljače 1799., arhiđakonom našega kaptola. Bio je generalni vikar nadbiskupa Carsane, a nakon njegove smrti generalni i kaptolski vikar, izabran aklamacijom 17. prosinca 1800., potom ponovno generalni vikar nadbiskupa Scottija, zatim ponovno generalni i kaptolski vikar od njegove smrti do 1823. godine, te na kraju, nadbiskupski vikar u vrijeme Nowaka."

70 ADBCT, Glagoljska madrikula Svećeničke bratovštine zadarskih otoka Večere gospodnje. Registro della confraternita „Coena domini“ dell' isola di Ugliano anno 1617., sign. R. P. MS 2-2, fol. 26v.

71 O životu i radu ovog svećenika vidi G. Franov-Žıv ković, Glagoljaš don Ive Vlahić, 147 - 183. 
U Madrikuli nalazimo na tri stranice zapisane dijelove Svetog pisma koji se odnose na liturgiju mise Večere gospodnje na Veliki četvrtak, koje je zapisivao don Ive Vlahić.

Kao što kapitul treći nalaže, braća biraju svoje sudce, a upravno tijelo bratovštine sačinjavaju dva (ili tri) ${ }^{72}$ sudca (vikarij ili glavni sudac te prokaratur) te jedan zapisničar (kančilir). Zanimljivo da braća glasuju (glasom ili balotama) samo za glavnog sudca (starešinu, vikarija), dok on kasnije bira svoje pomoćnike (prokarature) i zapisničara. ${ }^{73}$ To potvrđuju i zapisnici s godišnjih skupština koji nisu kompletni, tj. postoje za samo nekoliko godina. Godine 1815. javlja se položaj ceremoniste u bratovštini, koji se bira po redu ulaska u bratovštinu, za koju je izabran don Pave Perić, a koji je u skladu s kapitulom 17 dužan u slučaju da ne može obnašati dužnost, prebaciti svoju dužnost na don Mihu Karlovića. ${ }^{74}$

Svake je godine biran domaćin župe u kojoj će se iduće godine održati godišnja skupština, što se možda poklapalo is tim da je tu dužnost dobivao sudac iz prethodnog razdoblja, kao u laičkim bratovštinama.

$\mathrm{Na}$ osnovi postojećih zapisnika možemo napraviti tablicu sudaca bratovštine za iste godine. ${ }^{75}$

72 U kasnijim zapisnicima pojavljuju se dva prokaratura, a ne samo jedan kao u ranijim.

73 Ovakav način izbora pronađen je u laičkoj bratovštini sv. Mihovila u Vrsima. AZDN, Glagoljska madrikula Bratovštine sv. Mihovila 1700. - 1822.

74 ADBCT, Glagoljska madrikula Svećeničke bratovštine zadarskih otoka Večere gospodnje. Registro della confraternita „Coena domini“ dell” isola di Ugliano anno 1617., sign. R. P. MS 2-2: „Na 16 otobra 1815 / Ja d(on) Pave Peric brat scule Veçere Gospodinove buduchi godischa 1814 da su me bracha odredila da buden ceremonista od iste scule buduchi da me tukali po redu a sada $s$ mojon volion is Boxjin (h)otinjem buduchi da su dosla moja godischa i ne moguchi obsluxiti one duxnosti coja me od obnigiva ista s(veta) scula dopuschenjem i jodrechujem i s dogovorom sve brache postavlam isto brime na postovanoga gospodina $\mathrm{d}(\mathrm{on}) \mathrm{Mihu}$ Carlovicha: caco brata od iste scule da oni obsluxe one iste duxnosti cu zapovida ova ista scula i za bole virovane potvirchujem / don Pave Perich potvrju(jem) / don Miho Carlovich primihi dobrovolno.“

75 Na osnovi istih zapisnika saznajemo i koji su bili sudci iz prethodnog razdoblja. 
TABlica 1. Popis sudaca svećeničke bratovštine zadarskih otoka Večere gospodnje (Coena Domini). (Izvor: Archivio Diplomatico della Biblioteca Civica di Trieste, Madrikula Svećeničke bratovštine zadarskih otoka Večere gospodnje).

\begin{tabular}{|c|c|c|c|c|c|c|}
\hline $\begin{array}{l}\text { Datum } \\
\text { braśćine }\end{array}$ & \begin{tabular}{|l} 
Mjesto \\
održavanja \\
braśćine
\end{tabular} & 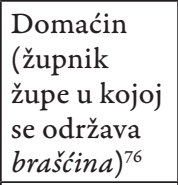 & Vikarij & $\begin{array}{l}\text { Prokaratur } \\
\text { I }\end{array}$ & $\begin{array}{l}\text { Prokaratur } \\
\text { II }\end{array}$ & Kančilir \\
\hline 1700. & ??? & ??? & \begin{tabular}{|l} 
Don ??? \\
Šlaka ${ }^{77}$ \\
\end{tabular} & $\begin{array}{l}\text { Don Filip } \\
\text { Duničić }\end{array}$ & & \\
\hline $\begin{array}{l}12.4 . \\
1701 .^{78} \\
\text { (utorak) }\end{array}$ & \begin{tabular}{|l|} 
Puntadura \\
(Vir) u crkvi \\
gospodina \\
C̆arnice
\end{tabular} & \begin{tabular}{|l|} 
Don Stipe \\
Melada iz \\
Lukorana \\
Župnik Vira
\end{tabular} & $\begin{array}{l}\text { Don Ive } \\
\text { Kačan iz } \\
\text { Sutomišćice }\end{array}$ & $\begin{array}{l}\text { Don Šime } \\
\text { Velislović iz } \\
\text { Sutomišćice }\end{array}$ & & $\begin{array}{l}\text { Don Erko Špar } \\
\text { parokian od } \\
\text { S(vete) Fume } \\
\text { prek imena zvan } \\
\text { (nadimkom) } \\
\text { Ecetera }\end{array}$ \\
\hline 1703. & & & \begin{tabular}{|l} 
Don Ive \\
Kačan iz \\
Sutomišćice \\
\end{tabular} & $\begin{array}{l}\text { Don Frane } \\
\text { Šimarina iz } \\
\text { Uglana } \\
\end{array}$ & & \\
\hline $\begin{array}{l}8.4 .1704 . \\
\text { (utorak) }\end{array}$ & $\begin{array}{l}\text { Ugljan, } \\
\text { crkva svete } \\
\text { Marije } \\
\end{array}$ & & $\begin{array}{l}\text { Don Šime } \\
\text { Velislović iz } \\
\text { Sutomišćice }\end{array}$ & $\begin{array}{l}\text { Don Filip } \\
\text { Duna iz } \\
\text { Lukorana }\end{array}$ & & $\begin{array}{l}\text { Don Jerko Špar } \\
\text { iz istoga sela di } \\
\text { Šanta Femia }\end{array}$ \\
\hline $\begin{array}{l}3.5 .1757 .7^{79} \\
\text { (utorak } \\
\text { prije obida) }\end{array}$ & $\begin{array}{l}\text { Lukoran, } \\
\text { crkva sv. } \\
\text { Lovrinca }\end{array}$ & $\begin{array}{l}\text { Don Miho } \\
\text { Telac }\end{array}$ & \begin{tabular}{|l|} 
Don Stipe \\
Mikljanić od \\
Brbinja
\end{tabular} & & & \\
\hline
\end{tabular}

76 Postoji mogućnost da je domaćin te godine jedan od sudaca iz ranijeg razdoblja te da se u njegovoj župi održavao izbor kao u u bratovštini Sv. Duha Ravnih kotara: HR-DAZD, Dračevac, Libar od skule Duha Svetoga godišća Gosp. 1691., Per 10/a; I AZDN, Kožino, Madrikula bratovštine Svetog Duha 1713. - 1818.

77 Bakitu je predao prokaratur od prošle godine Filip Duničić, glavni sudac, vikarij od prošle godine bio je go(spodi)n Šlaka iz Uglana. Bakita je vaketa, knjiga računa. Jakov Jelınčıć, Dnevnik rada popisivanja gradiva crkvenih arhiva porečke i pulske biskupije te pazinske apostolske administrature (18. prosinca 1970. - 28. listopada 1980), VIA, svezak 25, 58, 59. fusnota 17: „Imenicu vacheta i vaceta nalazimo u talijanskim i latinskim rječnicima, prvu kao vrstu broda, a drugu kao vrstu tkanine. U ovom je smislu nalazimo jedino u rječniku Gianni Pinguetini, Nuovo dizionario del dialetto triestino Storico Etimologico Fraseologico, kao računsku knjižicu, tj. Knjižicu iz koje se kasnije prepisivalo u čisto, nazvano prema uvezu u štavljenu kožu.“

78 ADBCT, Glagoljska madrikula Svećeničke bratovštine zadarskih otoka Večere gospodnje. Registro della confraternita "Coena domini“ dell” isola di Ugliano anno 1617., sign. R. P. MS 2-2. Primjer jednog zapisnika s godišnje skupštine: „1701 miseca aprila na 12 / Ovdi te se pisati u napridak vikarii za da ki ko godišće bude da se znade / Don Ive Kačan iz Sutumišćice bih učinen vikarii skule Bule Vičere Go(spodi)n(ove) a to na Puntaduri na brašćini u don Stipe Melade iz Lukorana ki tada biše $\mathrm{u}$ to doba tote za parokiana tote $\mathrm{i}$ ja isti don Ive Kačan priah bakitu od Filipa Duničića prokaratura po(štovanoga) go(spodi)na Šlake iz Uglana a to parvi dan po misi utorak a u crikvi gospo(di)na Čarnice a odabrah za moga prokaratura poštovanoga go(spodi)na don Šimu Velislovića iz istoga sela ednoga i kančilira moga parokiana od S(vete) Fumie don Erko Špar prek imena zvan Ecetera. Amen.“ U zapisniku nije naveden stari vikarij koji predaje bakitu novome. 


\begin{tabular}{|c|c|c|c|c|c|c|}
\hline 8. 5. 1764. & Sutomišćica & $\begin{array}{l}\text { Don Miho } \\
\text { Pavin }\end{array}$ & \begin{tabular}{|l|} 
Don Mate \\
Brižić iz \\
Sutomišćice
\end{tabular} & $\begin{array}{l}\text { Don Šime } \\
\text { Belić od } \\
\text { Uglana }\end{array}$ & & \\
\hline 5.5.1765. & & & $\begin{array}{l}\text { Don Pave } \\
\text { Grdović od } \\
\text { Sutomišćice }\end{array}$ & $\begin{array}{l}\text { Don Šime } \\
\text { Ivanov }^{81}\end{array}$ & & $\begin{array}{l}\text { Don Miho } \\
\text { Nižić }\end{array}$ \\
\hline 15. 5. 1770. & Ugljan & $\begin{array}{l}\text { Don Miho } \\
\text { Vuković }\end{array}$ & \begin{tabular}{|l} 
Don Pere \\
Švorcina od \\
Uglana \\
\end{tabular} & \begin{tabular}{|l} 
Don Mate \\
Brižić iz \\
Sutomišćice \\
\end{tabular} & & \\
\hline $1771 .^{82}$ & Sutomišćica & \begin{tabular}{|l|} 
Don Ive \\
Vlahić
\end{tabular} & & & & \\
\hline 1772. & Sutomišćica & $\begin{array}{l}\text { Don Šime } \\
\text { Šimić }^{83} \\
\end{array}$ & & & & \\
\hline 2.5. 1773 . & Sutomišćica & $\begin{array}{l}\text { Don Ante } \\
\text { Barić } \\
\end{array}$ & $\begin{array}{l}\text { Don Jerko } \\
\text { Kaštelanić }\end{array}$ & & & \\
\hline $1774^{84}$ & & & \begin{tabular}{|l|} 
Don Jure \\
Kuštera \\
\end{tabular} & & & \\
\hline $\begin{array}{l}4.11 . \\
1807 .{ }^{\circ 5}\end{array}$ & $\begin{array}{l}\text { Preko, B. } \\
\text { Gospa od } \\
\text { Luzaria }\end{array}$ & \begin{tabular}{|l|} 
Lovre \\
Dorkić
\end{tabular} & $\begin{array}{l}\text { Kanonik don } \\
\text { Šime Perić }\end{array}$ & $\begin{array}{l}\text { Don Jerko } \\
\text { Šarić }\end{array}$ & $\begin{array}{l}\text { Don Jure } \\
\text { Vlahić }\end{array}$ & $\begin{array}{l}\text { Don Jive } \\
\text { Koštin vikarij } \\
\text { izvanski i } \\
\text { parokijan od } \\
\text { Preka }\end{array}$ \\
\hline
\end{tabular}

80 P. Kero, Leksikon svećenika Zadarske nadbiskupije (u rukopisu): „Brižić, Mate, rođen u Preku 1702. godine. Bianchi, (II., str. 119, 89 i 105) navodi mjesta njegova župnikovanja: Banj-Ždrelac 1737. i 1746. Na nadvratniku glavnih ulaznih vrata urezan je natpis latiničnim slovima: "Na XI luia ili zunjia 1730. bi uzidana ova crikva od ovoga komuna u vrime paroka D. Matte Brixicha”. Madrikula s. Tila u Banju 38 i 40. Ugljan 1741.-1743. i Sutomišćica 1743. godine. Godine 1760. kum je na krizmi u Brbinju kao župnik Sutomišćice (MKr Brbinja). Župnik u Sutomišćici od 1743. do 1762. (MK Sutomišćica). Spominje se 1750. u Glagoljskoj knjizi dobra župe sv. Nikole u Istu. God. 1774. je spomenut u Extr. (I. str. 164). Umro je u Sutomišćici 1777. (MU Sutomišćica). „Na 17. V. god po. don Mati Brižiću parokianu 1777.”“ (KG Sutomišćica; KG Preko). DAZD, Glagoljska matica umrlih Sutomišćica 1765. - 1825.: „1777 na 16 maja priminu dobri i vridni naučitel don Mate Brižić vikarij i parok s(ve)te crikve od godišć 75 incirka priminu u viri s(ve)te matere crikve Rimske umri u gradu u seminariju arvaskim bi ispovidan i prićešćen $s(v e) t i m$ uljem pomazan bi mu preporučena duša i bi pokrepljen načas od smarti od redovnikov onoga grada bi sprovodjen od don Mate Nižića njegova kapelana bi pokopan u crikvi Blažene Gospe od Luzarija u Preku Bog mu da rajsko stanje.“

81 Grdović zvani Ivanov.

82 Na temelju note od robe, tj. Zapisnika od 13. svibnja 1772.

83 Na temelju note od robe, tj. Zapisnika od 13. svibnja 1772.

84 ADBCT, Glagoljska madrikula Svećeničke bratovštine zadarskih otoka Večere gospodnje. Registro della confraternita „Coena domini“ dell' isola di Ugliano anno 1617., sign. R. P. MS 2-2. Ne postoji zapisnik s godišnje skupštine, nego samo izvješće o stanju računa bratima Pavla Rančića koje glasi: „1744 na 9 zuna / Budući izvidi i razvidi sve police našega brata Pavla Rančića i dužnost kako nas obniga ova madrikula toliko ko za braću martvu koliko ostali obnizi nas obnigavaju kapituli najdoh da je dosad ispuni sve mise $i$ čini ispuniti od naše braće redovnikov kako vidim $u$ istih recevudah od nih ucinene a meni prikazane kančiliru don Anti Brižiću prid vikarijem don Juron Kušterom / Ja don Jure Kuštera vikarij.“

85 Promijenio se datum godišnje skupštine s travnja ili svibnja na studeni. 
Osim bratima, svaka svećenika bratovština $u$ svoje redove prima $i$ uglednije članove društva, ${ }^{86}$ laike kao što su veleposjednici, obrtnici, paruni (brodovlasnici) ili članovi vojnih i civilnih vlasti. Pri kraju madrikule nalazimo popis svjetovne braće.

Ovdi ćemo zapiševati mundani ${ }^{87}$ ki budu dobodili $k$ nam u ovu svetu skulu udil dobar duhovnik (pokraj svakog imena dodano je dilnik dobar duhovnih).

TABLICA 2. Popis svjetovne braće svećeničke bratovštine zadarskih otoka Večere gospodnje (Coena Domini). (Izvor: Archivio Diplomatico della Biblioteca Civica di Trieste, Madrikula Svećeničke bratovštine zadarskih otoka Večere gospodnje).

\begin{tabular}{|l|l|l|}
\hline Gospodin Frane Bartulačić & Gospodin Frane Civalelić & Barba Ivan Brunac iz Barbina \\
\hline $\begin{array}{l}\text { Barba Erolim Markodin iz } \\
\text { Ista }\end{array}$ & Gospodin Gargo Detrišić & Parun Gaspar iz Ista \\
\hline $\begin{array}{l}\text { Gospodin Marko Danić iz } \\
\text { Ista }\end{array}$ & Parun Erolim Babajko iz Ista & Ivan Sobotić iz Puntadure \\
\hline Mikula Mandul iz Grada & $\begin{array}{l}\text { Gospodin Ante Ferara iz } \\
\text { Grada }\end{array}$ & $\begin{array}{l}\text { Gospodin Ante Bartulačić iz } \\
\text { Grada }\end{array}$ \\
\hline Gospodin Ere Vitanovi(ć) & $\begin{array}{l}\text { Parun Mate Baćoka iz } \\
\text { Božave }\end{array}$ & $\begin{array}{l}\text { Gospodin Anzu(l) Fafunić iz } \\
\text { Grada }\end{array}$ \\
\hline Gospodin Ive Peruzić & Mate Božičević od Sestrunja & Ive Mičić od Sutomišćice ${ }^{88}$ \\
\hline $\begin{array}{l}\text { Jerolim Šimićev iz } \\
\text { Sutomišćice }\end{array}$ & Gospodin Alviž Detrešić & Gospodin dotur Švatoć(!). \\
\hline Gospodin Zaneto Manoli & $\begin{array}{l}\text { Parun Šimun Ivanušić iz } \\
\text { Silbe }\end{array}$ & Barba Mate Karlović iz Ugljana \\
\hline
\end{tabular}

S obzirom na to da je riječ o boljestojećim građanima, njihova je uloga bila i kao dobročinaca, ${ }^{89}$ pa nalazimo na kraju popisa i dva primjera zadužbina (laši) bratima Pere Našića (Nassi) iz Zadra ${ }^{90}$ i meštra Jakova Jadrošića iz Premude. ${ }^{91}$

86 Na primjer, Zavičajni muzej Biograd na Moru, Madrikula Bratovštine Uznesenja Blažene Djevice Marije u Biogradu 1720. - 1841.

87 Svjetovna braća.

88 Oporuka kapetana Ive Mičića od 8. ožujka 1763., HR-DAZD-20, Zadarski knez, knjiga III, 177ab; Grozdana Franov-Žıvković, Društveni položaj pripadnika mletačkih teritorijalnih snaga (černida) sa zadarskog područja u 17. i 18. stoljeću na temelju glagoljskih matičnih knjiga i ostalih dokumenata, Acta Histria, 26, Koper, 2018., 473 - 502.

89 Tj. dobročinitelja.

90 ADBCT, Glagoljska madrikula Svećeničke bratovštine zadarskih otoka Večere gospodnje. Registro della confraternita „Coena domini“ dell” isola di Ugliano anno 1617., sign. R. P. MS 2-2: „Gos(podi)n Pere Našić bi dilnik dobar i darova braći libar tristo i deset da mu se kanta edna misa na godišće u crkvi s(vetoga) Duminiga u Zadru meju ostalu.“

91 ADBCT, Glagoljska madrikula Svećeničke bratovštine zadarskih otoka Večere gospodnje. Registro della confraternita „Coena domini“ dell' isola di Ugliano anno 1617., sign. R. P. MS 2-2: „Meštar Jakov Jadrošić iz Premude darova skuli cekin dvaest 1720(?) da mu se kanta edna misa na godišće.“ 
Uz postojeće zapisnike na kraju madrikule nalazimo i popise bratima koji ne daju sviće s datumom iz 1768. te popis onih koji nisu dali sviće, nota od redovnika koji nisu došli na obtabu Božjeg dne 13. lipnja 1730. i 29. svibnja 1731. Tu su razni primitci i rashodi, koji su vjerojatno bili upisivani u posebne evidencije primitaka i rashoda, a koje nisu sačuvane. Tu su i dijelovi laši bratima, kao npr. roba pokojnog Melade.

U lipnju 1735. u Zadru na obtavu Božjega dni zapisana je još jedna odredba u kojoj se osobi (bratimu) koja je izabrana za putovanje u Asiz treba skupiti novac ili iz blagajne bratovštine dati 220 libara.

\section{BRATOVŠTINA COENA DOMINI U GLAGOLJSKIM OPORUKAMA}

Članovi ove svećeničke bratovštine ostavljali su za zadudžbine (zadušine, zadušbine, laše, legate) svojoj subraći zemljišta, libre (knjige), kuće, novac i ostala pokretna i nepokretna dobra da mole za njihovu dušu. Ovo je sve ostalo zapisano u oporukama.

Don Mate Pribić iz Ugljana ${ }^{92}$ 1659. godine ostavlja braći Vičere Go(spo)dinove šotanu 1 i drugu ka ni kroena (koja nije dovršena) i 1 prsten od zlata. Uz spomenutu svećeničku bratovštinu don Mate spominje i laičku bratovštinu Božjeg Tila (Sv. Sakramenta) u Svetoj Stošiji (vjerojatno u Olibu) te laičku bratovštinu Sv. Duha na Velom Ižu. ${ }^{93}$

Don Miško Duničić iz Lukorana piše oporuku 1764. godine te moli svoje nasljednike da prime braću Večere Gospodinove kad dođu na njegov sprovod kako se pristoji: Ostavlan kada mi doidu moja braća redovnici na sprovod da im se dade obid $i$ da im se učini pristoeno i ove sve da se učini od moga očinstva ako ne bi hoti Bože ispuniti ove naredbe i prijati redovnici da don Šime ispuni da podloži masline na Didinah sve ča e na Capićevu i na Sagićevu ostavlan od onih masline dan cekin braći Bule Vičere Gospodinove. Na kraju oporuke dodaje Ostavlan vosak vas izvan enoga dunplira crkvi a edan skuli. ${ }^{94}$

92 P. Kero, Leksikon svećenika Zadarske nadbiskupije (u rukopisu): „Pribić, Matij, rođen u Ugljanu. Godine 1605. kao „žakan“ kumovao na krštenju u Ugljanu. MK I, 11, a g. 1609. kao svećenik: ibidem 24. Od 1616. do 1630. bio je uz neke prekide kapelan u Ugljanu. MK II., 60-125. Bianchi II., 83 ga donosi god. 1657. kao župnika u Velom Ižu. G. 1659. kao župnik u Velom Ižu učinio je svoju glagoljsku oporuku (Državni arhiv Testamenti I, str. 331).“ S obzirom na to da po oporuci ostavlja neku imovinu i bratovštini Božijeg Tila u Sv. Stošiji na Olibu, možemo pretpostaviti da je u nekom razdoblju djelovao kao župnik ili kapelan u Olibu.

93 HR-DAZD-20, Fond Zadarskih knezova, Oporuke, knjiga I, br. 326ab, 331 / Oporuka don Mate Pribića, 27. 1. 1659.: „Pušćam braći Vičere Go(spo)dinove šotanu 1 i drugu ka ni kroena i 1 prsten od tlata i drugi Ivanu žaknu.“

94 HR-DAZD-20, Fond Zadarskih knezova, Oporuke, knjiga III, 439. 
Don Ante Dorkin iz Preka 1765. godine također upućuje svoje nasljednike da lijepo dočekaju njegovu subraću iz Skule Večere Gospodinove kada dođu na njegov sprovod, ako ne bude novaca da se počaste, traži da se proda kota. ${ }^{95}$

Don Pave Grdović, 1763., župnik Sukošana, rodom iz Sutomišćice, gdje želi da ga se i pokopa, također je bio bratim ove skule, kojoj ostavlja u oporuci dva cekina i dodaje: $A$ sada narejujem da moji sinovci imaju učiniti karminu po braći od skule Vičere Gospodinove. Don Pave u isto je vrijeme bio član još dvije bratovštine, svećeničke bratovštine u Biogradu ${ }^{96}$ te svećeničke Bratovštine Gospe od Milosrdja, koja je djelovala na području njegove Župe Sukošan. ${ }^{97}$

Nešto dužu naredbu svojim nasljednicima vezano za subraću ove bratovštine ostavlja don Jure Švorcina iz Ugljana, 4. listopada 1776. svojoj subraći ostavlja pet filipa koji će poslužiti da se netko od bratima pošalje na hodočašće u Asiz da moli za njegovu dušu: Nareduen da redovnici ki budu na momu sprovodu da imadu se zvati na obid drugo nareduen momu sinovcu don Juri i mojoi braći i sinovcem da imaju učiniti moji pogreb skuli Bule Večere Gospodinove oli dati pinezi oli ih zvati u kući budući da sva moja stečenja da san in u kući i ako bi me sada diga Gospodin Bog od ovoga svita nareduen don Juri i braći da imaju datoj braći od skule Bule Večere Gospodinove pet filipa da pošalu za me u Vasiž ostavlam kako je zadano $u$ kančelariji. ${ }^{98}$ Don Miho Pavin 1776. također moli braću da pošalju nekoga u Asiz da moli za njegovu dušu. Usto im preporučuje nećaka da ga školuju za svećenika na način kako bi on to napravio: Kad mi se prigodi smart da se kupi šest dunpliri savaki od cikini i da se jave po braći od skule Vičere Gospo(dino)ve i svi redovnici ki dojdu na sprovod da se dočekaju na obid. Ostavljam braći skule Vičere Gospo(di)n(ov)e cikini tri a da oni pošalju za me u Asiž moga sinovca don Šimu koga priporučujem istoj braći da ga uče $i$ karaju, a on da bude nimi poslušan $i$ podložan u svemu. ${ }^{99}$

Iz oporuke don Ante Mičića nije vidljivo iz koje su bratovštine redovnici koji trebaju prisustvovati njegovu pogrebu, a iz popisa braće madrikule Večere Gospodinove nije vidljivo da je bio bratim ove bratovštine jer je zadnji popis

95 HR-DAZD-20, Fond Zadarskih knezova, Oporuke, knjiga III, 509.

96 HR-DAZD-20, Fond Zadarskih knezova, Oporuke, knjiga III, 420, 421ab; Zavičajni muzej Biograd na Moru, Madrikula Bratovštine Uznesenja Blažene Djevice Marije u Biogradu 1720. - 1841.; Pavao Kero, Grozdana Franov-Živ ković, Milan Perović, Biogradska glagoljska madrikula Bratovštine Uznesenja Blažene Djevice Marije 1720. - 1841., 2012.

97 HR-AZDN, Glagoljska madrikula Bratovštine Gospe od Milosrđa 1728. - 1818.; P. KERO, Popis glagoljskih kodeksa Zadarske nadbiskupije, drugo izdanje, 96; Članak o sukošanskim bratovštinama je u tisku.

98 HR-DAZD-20, Fond Zadarskih knezova, Oporuke, knjiga IV, 332b.

99 HR-DAZD-20, Fond Zadarskih knezova, Oporuke, knjiga IV, $545 \mathrm{ab}$. 
bratima iz 1786. godine pa se ne zna je li nakon tog datuma stupio u bratovštinu. Postoji vjerojatnost da jest jer je njegov otac kapitan Ive Mičić u popisu svjetovnih članova ove bratovštine. ${ }^{100}$

Don Jerko Šimić također ne navodi kako se zove bratovština čiji redovnici moraju prisustvovati njegovu sprovodu, ali je iz popisa bratima u madrikuli vidljivo je da je bio bratim Večere Gospodinove. ${ }^{101}$

Don Grgo Sandalić u oporuci od 22. lipnja 1792. piše: .... i da mi se učini sprovod iz mojih dobar kako se pristoji i da se dade u skulu braći za moj pogreb cekin 6. Nije naveo naziv bratovštine, ali je u popisu članova Večere Gospodinove. ${ }^{102}$

Don Šime Šimić u oporuci od 16. listopada $1792 .{ }^{103}$ moli nasljednike da mu dovedu na sprovod subraću Večere Gospodinove, koju spominje više puta: kad mi se progodi moja smart priporučujem mojim eredom da mi učine moj sprovod kako se bude moći najbolje od moih dobar i da se jave braći redovnikom od skule Večere Gos(podino)ve da dojdu na moj sprovod i da im se da obid... Dalje dodaje: ostavljam da se proda suba carna, i barvija i da se od toga dade braći skule Večere Gos(podino)ve tri cekina, zada rečena braća pošalju za me u Asiž, ako li bude što uzmankati da mi se čine reći toliko mise....

\section{ZAKLJUČAK}

U prošlosti je na zadarskom području zabilježen veći broj bratovština, nešto više laičkih (vjerskih i obrtničkih), a nešto manje svećeničkih. Većina ovih bratovština do sada nije obrađena. Nije točno definiran ni njihov broj, ciljevi i zadatci, a ni razdoblje djelovanja. Na početku članka pokušava se na temelju dosadašnjih spoznaja definirati broj svećeničkih bratovština na zadarskom području, u samom Zadru te na otocima i na kopnenom dijelu. Iako će daljnja istraživanja vjerojatno donijeti nove rezultate i promijeniti ove podatke, za sada bilježimo osam svećeničkih bratovština u samom Zadru, četiri na kopnu i šest na otocima. U članku je analizirana novootkrivena glagoljska madrikula

100 HR-DAZD-20, Fond Zadarskih knezova, Oporuke, knjiga VI, br 68: „U Sutomischizi na 2 decembra 1787. Gia dijak don Ante Micich din od pok(ojnoga) Kapitana Jive Miçicha...kada se prigodi moja smart da moj brat Ossip uçini mi moj sprovod kako bude mochi boglie i redovnici ki budu na sprovodu da im naredi da reku misse za moju dusu i da budu plachieni od istoga moga brata Osipa.“

101 HR-DAZD-20, Fond Zadarskih knezova, Oporuke, knjiga VI, 418ab: Ka(pitul) 1 ako bi mi se prigodila smrt da mi se ućini sprovod što se more bole $i$ da se zovu svi redovnici na moi sprovod da mole Boga za me. Na 23 novembra 1793. Transliteracija oporuke objavljena u članku G. FrANovŽıv ković, Život i djelo glagoljaša don Jerolima Kuzmića Šimića, 89 - 102.

102 HR-DAZD-20, Fond Zadarskih knezova, Oporuke, knjiga VI, 377ab.

103 HR-DAZD-20, Fond Zadarskih knezova, Oporuke, knjiga VI, 401 ab. 
svećeničke bratovštine zadarskih otoka Večere Gospodinove sa sjedištem u mjestu Ugljan na otoku Ugljanu za koju se do nedavno mislilo da je izgubljena. Bratovština je osnovana (ili obnovljena) 1617. godine, a članovi ove bratovštine bili su svećenici sa sjeverozapadnog dijela otoka Ugljana, prvenstveno mjesta Ugljan, Lukoran, Sutomišćica, Poljana i Preko, te dijelom svećenici s otoka Iža, Oliba, Molata, Silbe, Premude, Vira i sjeverozapadnog dijela Dugog otoka. Sačuvan je 31 kapitul, popisi bratima svećenika i jednog malog broja laika (uglavnom su upisani veleposjednici, paruni, glavari sela i kapetani) te razni drugi zapisi vezani uz rad bratovštine. U bratovštinu su bila učlanjena i dva zadarska nadbiskupa i jedan skradinski. Zadnji zapisi sežu do 1816. godine. U ovu bratovštinu bio je upisan i jedan dio svećenika čiji su glagoljski zbornici tekstova do danas ostali sačuvani.

\section{PRILOZI}

Prilog 1. Pravila (kapituli) svećeničke bratovštine zadarskih otoka Večere gospodnje (Coena Domini). (Izvor: Archivio Diplomatico della Biblioteca Civica di Trieste, Madrikula Svećeničke bratovštine zadarskih otoka Večere gospodnje).

\section{7 na 27 novembra}

Na slavu Isusovu i negove Svete Vičere ku učini svoin pridragin učenikom kada umi noge nihove u Veli četvrtak na vičeri

.kapitul parvi.

Ovo mi redovnici želeći biti učenici obrati iste Večere Isusove i da bismo mogli bolje uzdvignuti slavu Gospodinu Bogu, $i$ želeći ono ča bi bilo za spasene duš naši i i potaren(j)e grihov naših, i nato se iskupismo za služiti svete mise u crikvi svete Marie na Uglanu, činiti dobri redi i zakoni ki se budu u napridak obsluževali

.kapitul drugi.

I ovo mi braća naredismo da nas bude 30; bratov redovnikov namisto 12: učenikov Gospodinovih $i$ kada bi ki brat priminu od ovoga svita na negovo misto mogu priati drugoga redovnika koga bude braći drago i ugodno

.kapitul treti.

I ovo mi braća naredismo da bude jedan staresina meju nami koga braća obere koi bude guvernati ovu skulu odavati redi braći i ta isti starešina da ima biti poslušan i poštovan od braće $i$ ki brat ne bi hotil obslužiti ni učiniti poslub istomu starišini ono ča mu zapovida po pravici da ima platiti dukat jedan

.kapituč četvarti.

I ovo mi braća naredismo da se imamo lubiti meju sobon kako prava braća rojena i duhovna brez svake trohe i podj(e)jamstva i drugi ostali redovnici da imamo lubiti kakono braću 
svoju $i$ ako bi kada ki brat od ove svete skule činil ili učinil kokodir pod jamstvo ili zlim dilom ili zlom ričju suprotiva istomu bratu od ove svete skule Vičere Gospodinove da ima platiti dukat pet

.kapitul peti.

I ovo mi braća naredismo da se imamo kupiti na naši skupi vazda u tretu sredu po Vazmi na ovu službu svetih mis i kantajući sv(e)ti versi Vičere Gospodinove i druge stvari duhovne odnimlajući sve stvari svitovne ke su zle otamne a to da se imamo kupiti k onomu našemu bratu koga bude tukati to godišće ki ne dojde da ima platiti dukat: jedan.

.kapitul šesti.

I ovo mi braća naredismo da imamo davati vazda svaki brat u pomoć bratu ki bude ćiniti skup ili u koga se skupimo libre tri kada je bijo običaj ma namisto te pomoći jima se kantati 9 mis na intencijun digana novoga po braći komu naredi naš kančilir i jima držati notu od tih mis svaki kančilir

.kapitul sedmi.

I ovo mi braća odlućismo(!) da jimamo pomoći brata našega kada bi ga ka potriba ali nevolja našla a ne budući negov uzrok zač ovo je jedno dilo od milosardja

.kapitul osmi.

I ovo mi braća naredismo da se jimaju daržati sviće podobne i da se jimaju užigati kada budu /b/ braća u jedno za činiti službu i svaki brat ki e starji leto da ima biti poštovan govorenjem i sidenjem i svakim drugim dilon a naikoli od mladib kako se pristoi

.kapitul deveti.

I ovo mi braća naredismo kada ki brat primine od ovoga svita da ima svaki brat reći vijilii a to martvi oficii u crikvi i za oficiem misu za negovu dušu a to udile kako dozna da epriminu iz ovoga svita i da ima reći svaki brat za negovu dušu mis deset

.kapitul deseti.

I ovo naredismo mi braća kada ki brat primine iz ovoga svita da se imaju braća kupiti ondi za di bude tilo negovo pokopano za učiniti službu za negovu dušu a to onda kade(!) naredi starešina od braće a to pod penu dukat 1 a ne budući inpejen u ku stvar dubovnu a to po negovi kušencii.

.kapitul jedanadesti. ${ }^{104}$

I oćemo da ne mozi vikarij činiti zapiševati ni jednoga za brata prez balotanja braće dva dila

.kapitul dvanadesti.

I ovo naredismo da ima svaki brat da bude od ove iste skule Vičere Gospodinove da ima moliti Gospodina Boga za duše vsih karšćanov ki su priminuli od ovoga svita i da ima svaki brat govoriti po jednu misu svaki misec vazda za duše martvih svih karšćanov da ih Gospodin Bog oslobodi od muk od pargatorija a da ih privede u rajsku slavu amen.

.kapitul trinadesti.

104 Izbrisan je originalni tekst kapitula te je kompletno prepravljen novim rukopisom. 
I ovo naredismo mi braća da svaki ki bude od ove iste /iste/skule Vičere Gospodinove da ima moliti Gospodina Boga da Gospodin Bog obrani i pomože svetu mater crikvu a da potare $i$ pogubi erežiju ${ }^{105} i$ poluvirstvo $i$ da ima vazda svaki brat reći po ednu misu svaki misec da Gospodin Bog prosvitli sarce i pamet svin onim ki su suprotivnici svete matere crikve da bi se obratili i podložili Gospodinu Bogu i svetoj materi crikvi da i(m) amo moliti Gospodina Boga za uzdaržanje privedre Repuplike Bnetaške ${ }^{106} i$ za prisvi(t)l(og) a g(ospodi)na arcibiskupa zadarskoga $i$ za drugi guvernateli i uzdaržateli svete matere crikve $i$ duš karšćanskih da $n(a) s$ Gospodin Bog obrani od nepriatela i od zale nemoći /to est kuge $e^{107} / i$ od nagle smarti, $i$ od grada, i od svakoga zla a da nam dade Go(spodi)n Bog mir i spasenie dušan našim.

.kapitul četrnadesti.

I ovo naredismo ako bi se kada prigodilo da bi ki brat hotil refudati ili ostupiti od ove iste skule Vičere Gospodinove da ima platiti dukat edan korente.

.kapitul petnadesti.

I ovo naredismo da vse pene imenovane zgora u kapitulih da ih ima prijati starešina od braće ki bude ono vrime $i$ da ih razdili ubozim a ne $i$ nami.

.kapitul šesnadesti.

I ovo naredismo mi redovni/ni/ci braća od ove iste poštovane skule Vičere Gospodinove da ni edan naš brat od ove poštovane skule nima prijati ni učiti po ni edan način žakna ki bi odstupi i poša tja od popa a to od koga kodir brata našega ki e od ove skule.

.kapitul sedamnadesti. ${ }^{108}$

I ovo naredismo da ako bi ki brat odstupi od naših mistov veća godišća jima imenovati redovn(i)ka koi ima ispunivati mise službe i sve dužnosti skule $i$ kaštige ako bi pomanka /i ako bi u ovomu pomanka/ ili sa svim tim u rok pet godišć ne povrati se stanen u mista rečena budi prekrižen od braće.

.kapitul osamnadesti.

I ovo mi redovnici braća od ove skule naredismo i učinismo vazda kada bi bila ka potriba balotati ili glas dati za ku stvar starešina ki bude ono vrime mozi dati dva glasa ili dvi balote.

.kapitul devetnadesti.

I ovo mi redo(v)nici braća od ove iste skule Vičere Isusove mi ne mogući veće nego 30 braće da e zapisano živih da za veliku lubav i molbu ku imaju ostali redo(v)nici u ovu poštovanu skulu mi braća ućinismo i naredismo da mozimo prijati odaržati veće redovnikov toliko koliko bude drago veće dil braći $i$ to isto redovnici ki bi htili dojti pod av isti kapitul ka se u nem uzdarži mozite biti prijati a s voljom veće dil braće a oni ako se obećaju Isukarstu $i$ braći da nete pomankati ni refudati nigdare i da imaju biti podložni poda vsi kapituli i pene kako se udarži u madrikuli ni davati one iste tri libre /tri/ i prihoditi na skupi i činiti skup kada ga bude tukati.

105 Herezu.

106 Ovaj dio za uzdaržanje privedre Repuplike Bnetaške naknadno je dodan.

107 Ovaj dio to est kuge naknadno je dodan iznad teksta originalnog kapitula.

108 Originalni kapitul izbrisan je i preko njega napisan novi tekst drugim rukopisom. 
.kapitul dvadeseti.

I ovo naredismo meju nami da ako bi se pribodilo ko prigovaran(j)e ali pravda da ima pojti sudac i vazesti sobon četire najstarji u skupu ča oni učine da je dobro učineno.

.kapitul 21.

I ovo mi redovnici braća od ove iste skule Vičere Gospodinove učinismo i naredismo meju nami kada budu naši skupi da nimamo prizivati ni ednoga svitovnoga č(ovi)ka pod penu kako se bude nam viditi i starišini ki bude u no vrime

.kapitul 22.

I ovo mi braća redovni(ci) od skule Vičere Isusove naredismo i učinismo da ako bi ki naš brat meju nami ili na skupu ili van skupa učil ili gdi se hoće da bi se doznalo da e opsova ili ogardi ili ozloglasi a navlastito suprotivno starešini ili koga se oće brata našega od skule Vičere Isusove mozi biti iznet vanka i(s) skule ove svete Vičere Isu(s)ove i da ni veće naš brat. .kapitul 23.

I ovo mi redovnici braća od skule Vičere Isusove naredismo i učinismo ako bi ki brat naš od skule Vičere Isusove osramoti ili iska sramotom sestru ili rodicu ili nepću budi ka se hoće od kuće od roda našega brata od skule Vičere Isusove mozi biti kaštigan od arcibi(sku)pa a od braće ki bude u no vri(m)e i mozi biti iznet vanka i(s) skule Vičere Isusove i koi bi oćito pribiva u nečistoći.

.kapitul 24.

I ovo naredismo da se nima pri/i/mati veće braće nego da i bude $30 / 3 / 109$ i kade ki pomanka ki brat mozite poštovana braća prijati koga nim bude drago namisto trides (e)t $/ \mathrm{i}$ tri $/ .^{110}$ .kapitul 25.

I ovo naredismo kada bi ki brat od iste ove skule upal u kokodir krivicu ke su u kapitulih imenovane ako se ne bi hotil podložiti i dati u pokoru starešini i braći onako kako se uzdarži u kapitulih zgor rečenih $i$ on starešina ki bude u no vrime jima pojti dati na znane prisvitlomu gospodinu arbibiskupu zadarskomu ili negovu namisniku.

.kapitul 26.

I ovo mi redovnic(i) braća od skule Vičere Isusove oblubismo svi edinimi usti i sarcem da imamo hoditi svako godište o(!) Zadar u Svetu Stošiju prid Božje tilo ednu misu kantati a to meju oktavu Božjega dne a to z dopušćenen prisvitloga gospodina arbibiskupa ili negova vikarija zadarskoga, i ova misa da bude aplikana za uzdaržanja $i$ uzvišenja repuplike našega prived(ro)ga principa.

.kapitul 27.

Budući mi braća skupili se na Uglanu u crikvi Svete Marije oblubismo kada koga brata Gospodin Bog sudi iz ovoga svita da brat ki je najbližni brat do brata da jima dati na znane da jima dojti sprovoditi brata martvoga svaki ki bude moći a to pod penu dukat 6: dan toliko onomu ki ne bi doša koliko onomu ki se ne bi javi a to da se ne mozi nikor skužati ki bude avizan.

109 Naknadno dodan broj 3 (odnosno glagoljsko slovo v).

110 I ovdje je naknadno dodano $i$ tri. 
.kapitul 28.

Budući mi braća skule Vičere Gospodinove skupili se u Svete Fumije u Sutumišćici odlučismo svi zajedno da svaki brat ki primine od ove prisvete skule da svaki živi brat jima dati po tri libre za brata umaršega $i(d)$ a ovi pinezi jimaju se dati jednomu redovniku bratu našemu i da pojde u Ašiž za brata našega umaršega; a ko se lako sel ne bi naša koi naš brat od skule, mozi najti našstarešina drugoga redovnika, i poslati i da ovi rečeni pinezi bude dužan doniti, ili poslati na prvi skup ako bi se oglušija ne doniti jib na rečeni rok da plati libricu voska lednu/.

.1747 kapitul 29.

Mi braća skule Bule Vičere Isu(so)ve budući na skupu ubičajnomu sakupleni, i promišljujući velike trošne koe se čine na onih naših skupih od braće mlaje, i da sveto veće umnoživaju se spize koje sadanja vrimena ne dopuśćaju činiti dohoditi ćiniti robu od mistov odalečnih i broditi srebro priko mora s velikim rizikom i zato promišljajući ove uzroke sva braća jedinokupno odrediše, i zapovidaju braći koja u napridak budu činiti ovakovi skupi i braśćin, da nimaju prikaživati na rečeni stol jizbine, i vina od dalečnih mistov, a to muštardu, sir pijažentin, konfeturu ni jedne varste, kolačići, grozja muškat, ni vina frustiska, pošade srebarne i to pod penu dokat(!) 10 da ima uput platiti, ili biti prikrižen iz skule, i na tu svarhu zapovidamo da naš prokaratur kupi s pinezi od skule 36 pošad ke te lužiti za ovi naši skupi koe hoće pridavati jedan drugomu, čiste i po broju s pomnom našega kančilira.

.kapitul 30.

Budući braća skupljena na skupu običajnomu godišća 1760 u carkvu sv(e)te Fumije u Sutumišćici promišljajući da o sadašnja vrimena je /d/ došla velika draginja od svih' stvarih' za življenje odrediše /d/da u napridak za ona dva dana u koja nas jimade dočekati na stol naš digan da ne mozi pristaviti prid nas droge(!) jizb(i)ne nego samo ove ovdi u ovim kapitulu imenovane a to kruha, vina, manestre, kokoše, tripe, štud', meso kuhano i pečeno, sira samo od jedne varste, cipra, i ovo samo puru potribu, druge ni jedne jizbine, i za ovo učiniše sva braća balotacion za da u /n/napridak ovako bude bi balot dvaeset' kontra samo $d v i$.

.kapitul 31.

1803 u Sutumišćici mi braća skule S(vetoga) Sakramenta Večere Gospodinove odredismo da u napridak koi bi brat u napridak doša upisati se da ima biti podložan kapitulom za učiniti braštinu u napridak. 
Prilog 2. Madrikula Svećeničke bratovštine zadarskih otoka Večere gospodnje, 1617., 1. stranica, početak kapitula (pravila).

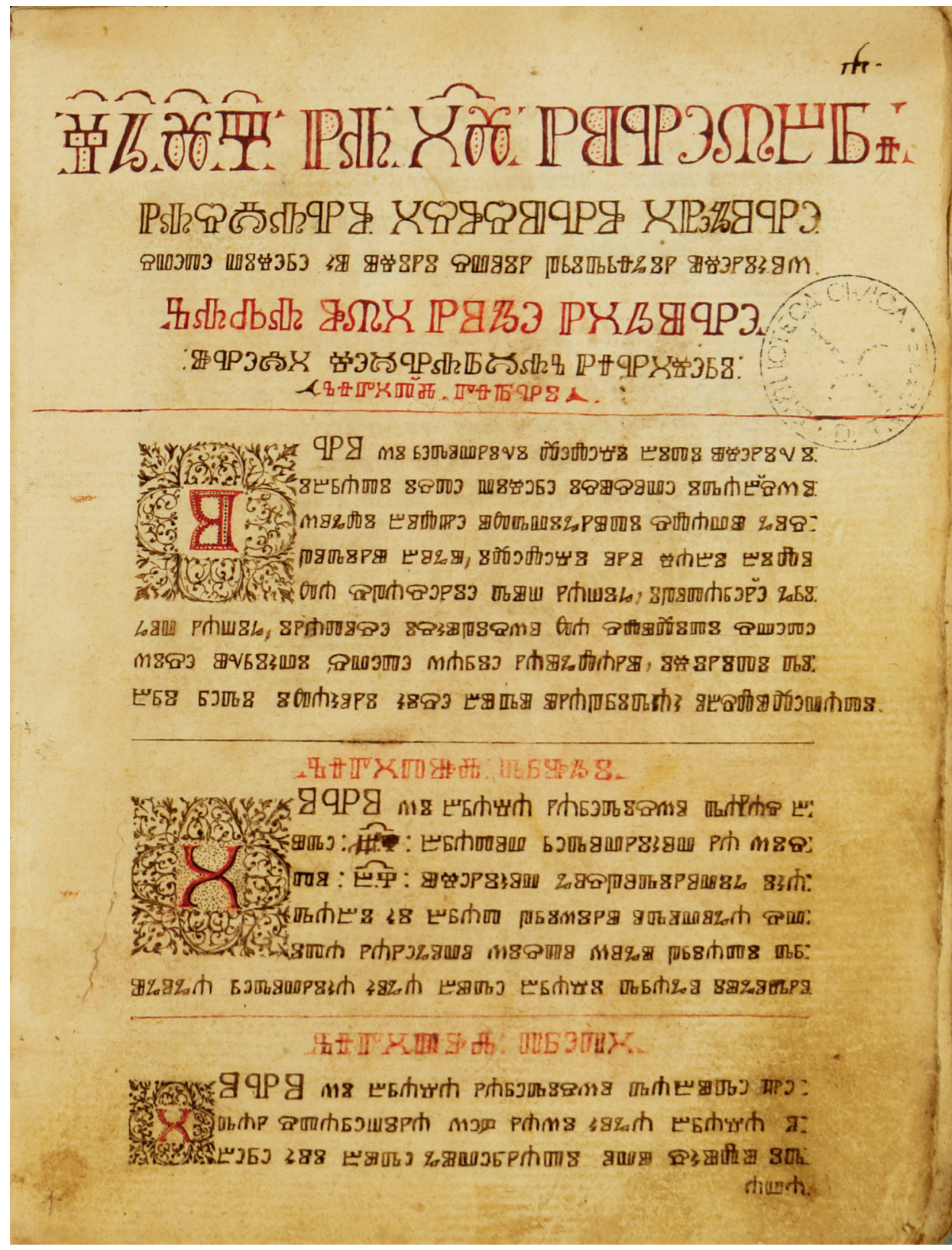

(Izvor: Archivio Diplomatico della Biblioteca Civica di Trieste, Madrikula Svećeničke bratovštine zadarskih otoka Večere gospodnje) 


\section{IZVORI I LITERATURA}

\section{IZVORI:}

\section{Archivio Diplomatico della Biblioteca Civica di Trieste (ADBCT)}

Madrikula Svećeničke bratovštine zadarskih otoka Večere gospodnje. Registro della confraternita "Coena domini“ dell' isola di Ugliano anno 1617. (sign. R. P. MS 2-2).

\section{Arhiv Zadarske nadbiskupije (AZDN)}

Glagoljska Madrikula svetog Mihovila u Vrsima (kod Nina), 1700. - 1822,

Glagoljska madrikula laičko-svećeničke Bratovštine sv. Karla Boromejskog 1640. - 1814.

Glagoljska madrikula Bratovštine sv. Petra i Pavla, 1727.

Glagoljska madrikula Bratovštine sv. Petra i Pavla 1729. - 1822.

Kožino, Madrikula bratovštine Svetog Duha 1713. - 1818.

Bratovština Blažene Djevice od Svetoga Ružarija 1644. - 1874., (Confraternitá della Beata Virgine del Santo Rosario, Scuola della Beata Virgine del Santo Rosario).

Bratovština Blažene djevice od Dobre radosti 1554. - 1821.

Olib, Glagoljska madrikula Bratovštine sv. Petra i Pavla, 1727.

Olib, Glagoljska madrikula Bratovštine sv. Petra i Pavla 1729. - 1822.

Sali, Glagoljska madrikula laičko-svećeničke Bratovštine sv. Karla Boromejskog 1640. - 1814.

Sali, Glagoljska madrikula Bratovštine Gospe od Milosrđa 1728. - 1818.

Fond Cvitanović, neobjavljeno.

Državni arhiv Zadar (HR-DAZD)

Zadarski knez, kut. I-VII.

Libar Bratovštine milosrđa (fond Strgačić)

Dračevac, Libar od skule Duha Svetoga godišća Gosp. 1691.

Bratovštine u Dalmaciji 1406. - 1880.

Sukošan, Glagoljska matica umrlih 1658. - 1759.

Sukošan, Glagoljska matica umrlih 1765. - 1799.

Sukošan, Latinička matica umrlih 1800. - 1826.

Glagoljska matica umrlih Sutomišćica 1765. - 1825.

\section{Zavičajni muzej Biograd na Moru}

Madrikula Bratovštine Uznesenja Blažene Djevice Marije u Biogradu 1720. 1841. 


\section{Arhiv HAZU}

Grdovićev zbornik, 18. st., sign. I d 40 (Kuk 748)

\section{Državni arhiv Split (HR-DAST)}

Iz katehizma Mihe Vukojevića rečenoga Milina iz Ugljana, 18. st., Arhiv obitelji Fanfogna-Garagnin, glagolitika.

Sukošan, Glagoljska matica umrlih 1608. - 1658.); Arhiv obitelji FanfognaGaragnin, glagolitika.

\section{LITERATURA:}

Acta Croatica = Listine hrvatske, izdaje: Ivan Kukuljević Sakcinski, Zagreb, 1863. Acta Croatica, Hrvatski spomenici. Hrvatske glagoljične i ćirilične isprave iz zbirke

Stjepana Ivšića 1100. - 1527., Knjiga I, prir. Josip Bratulić, Zagreb, 2017.

ANDRIć, Tonija, Socijalna osjetljivost obrtničkog sloja u Splitu sredinom 15. stoljeća, Historijski zbornik, god LXVI, 2013, Zagreb, br. 1, 1 - 23.

BENYOvsKY, Irena, Bratovštine u srednjovjekovnim dalmatinskim gradovima,

Croatica Christiana Periodica, god. XXII, br. 41, Zagreb, 1998., 137 - 160.

BertošA, Miroslav, Zlikovci i prognanici, Pula, 1989.

BERTošA, Miroslav, Izazovi povijesnog zanata, Lokalna povijest i sveopći modeli, Zagreb, 2002.

Bianchi, Carlo F., Kršćanski Zadar, II dio, Zadar, 2011.

Cronia, Arturo, Libar skule B. D. Marije od Milosrđa u Sukošanu kraj Zadra (1727), Prilozi za književnost, jezik, istoriju i folklor, knj. XVI, sv. 1, Beograd, 1936., 29 - 38.

Cvitanović, Vladislav, Bratovštine grada Zadra, Zbornik Zadar, Zagreb, 1964., $457-470$.

ČoRALIĆ, Lovorka, Izvori i literatura o bratovštinama u Dalmaciji od srednjeg vijeka do pada mletačke republike, Croatica Christiana Periodica, god. XV, br. 27, Zagreb. 1991., 88 - 96.

Franov-Žıvković, Grozdana, O kaljskim bratovštinama u razdoblju od 14. do 19 st., Zbornik Kali, Zadar, 2017., 175 - 236.

Franov-Živković, Grozdana, Bratovštine (Skule) župe sv. Mihovila u sv. Filipu i Jakovu u razdoblju od 17. do 19. st., Sv. Filip i Jakov, 2013.

Franov-Živković, Grozdana, Bratovštine (skule) župe sv. Eufemije (Fume) u Sutomišćici na Otoku Ugljanu u 18. st., Zbornik Odsjeka za povijesne znanosti Zavoda za povijesne i društvene znanosti HAZU u Zagrebu, 27, Zagreb, 2009., 165 - 227; 
Franov-Žıvković, Grozdana, Bratovštine (skule) župe Blažene Gospe od Luzarija u Preku na otoku Ugljanu u 18. st. i 19. st., Radovi Zavoda za povijesne znanosti HAZU u Zadru, 52, Zagreb-Zadar, 2010., 231 - 259.

Franov-Žıvković, Grozdana, Bratovština (skule) župe sv. Ivana Krstitelja u Tinju i župe sv. Petra i Pavla u Bubnjanima u 18. stoljeća, Radovi Zavoda za povijesne znanosti HAZU u Zadru, 53, Zagreb-Zadar, 2011., 163 - 187.

Franov-Žıvković, Grozdana, Glagoljska Madrikula sv. Jakova u Solinama na Dugom otoku (1750.-1826), Radovi Zavoda za povijesne znanosti HAZU u Zadru, 51, Zagreb-Zadar, 2009., 137 - 159.

Franov-Žıvković, Grozdana, Deković, Danijela, Prilozi istraživanju svakodnevnog života Vinjerca na temelju glagoljske knjige bratovštine sv. Antuna padovanskog i ostalih glagoljskih vrela od kraja 17. do početka 19. stoljeća, Radovi Zavoda za povijesne znanosti HAZU u Zadru, 60, ZagrebZadar, 2018., 205 - 248.

Franov-Žıvković, Grozdana, Glagolitic Confraternities Books of the Zadar Area and their Value as Historical Documents, Authority, Provenance, Authennticity, Evidence, selected papers from conference Authority, Provenance, Authenticity, Evidence, Zadar, Croatia, october 2016., ur. Mirna Willer, Anne J. Gilliland, Marijana Tomić, Zadar, 2018., 383 - 415.

Franov-Žıvković, Grozdana, Vigato, Ivica, Svakodnevni život Vlašića na otoku Pagu na osnovu zapisa iz glagoljskog kvaterana bratovštine Sv. Jerolima/Sv. Sakramenta i ostalih glagoljskih rukopisa iz 18. stoljeća, Radovi zavoda za povijesne znanosti HAZU u Zadru, 61, Zagreb-Zadar, 2019, $327-360$.

Franov-Žıvković, Grozdana, O kaljskim običajima u razdoblju od 15. do kraja 19 st., Zbornik Kali, ur. Josip Faričić, Zadar, 2017., 237 - 274.

Franov-Žıvković, Grozdana, Prezimena mjesta Pakoštane u 17. i 18. stoljeću na temelju glagoljske knjige duša, Radovi Zavoda za povijesne znanosti HAZU u Zadru, 55, Zagreb-Zadar, 2013., 59 - 92.

Franov-Žıvković, Grozdana, Biogradska glagoljska madrikula Bratovštine od Uznesenja Blažene Djevice Marije 1720. - 1841., u: Biogradska glagoljska madrikula Bratovštine Uznesenja Blažene Djevice Marije 1720. - 1841., ur. Pavao Kero, Zadar, 2012., VII - XV.

Franov-ŽIVković, Grozdana, Bratovštine Ninske biskupije, Znanstveni skup Ecclesia Nonensis: prošlost Ninske biskupije, Nin, 1. - 3. lipnja 2018., (u tisku). Franov-Žıvković, Grozdana, Sukošanske bratovštine od 17. do 19. stoljeća, Znanstveni skup Sukošan, rujan 2018., (u tisku). 
Franov-ŽIvković, Grozdana, Bratovštine otoka Pašmana i njihove glagoljske evidencije, Međunarodni znanstveni skup Fenomen glagoljice. Biograd Zadar, 12. i 13. svibnja 2017. (u tisku).

Franov-Živković, Grozdana, Društvena slika ugljanskih sela od 15. do 18. stoljeća prema podacima iz glagoljskih vrela, doktorski rad, Zadar, 2013.

Franov-Žıvković, Grozdana, Načini evidentiranja podataka u glagoljskim matičnim knjigama pisanima do 1825. godine na zadarskom području, Povijesni zbornik - godišnjak za kulturu i povijesno naslijeđe, br. 4 (God. III), Osijek, 2009., 79 - 124.

Franov-Žıvković, Grozdana, Zapisi iz knjige Bratovštine Gospe od Sniga u Sv. Donatu, Glagoljica u Zadru (drugi dio), Glasilo udruge glagoljaša Zadar Slovo rogovsko, br. 5, Zadar, 2017., 17.

Franov-ŽIvković, Grozdana, Glagoljski zapisi u dokumentaciji svećeničke bratovštine Blažene Djevice od Dobre radosti (Confraternita della Beata Vergine del Buongaudio). Glagoljica u Zadru (treći dio), Glasilo Udruge glagoljaša Zadar Slovo Rogovsko, br. 6, Zadar, 2018., 14 - 17.

Franov-Živković, Grozdana, Glagoljaš don Ive Vlahić (Sutomišćica, oko 1733. - 25.07.1803.), Radovi Zavoda za povijesne znanosti HAZU u Zadru, 54, Zagreb-Zadar, 2012., 147 - 183.

Franov-Živković, Grozdana, Don Jure Čubanov (Sutomišćica, oko 1754. Lukoran, 22. 10. 1830.), Zbornik sa znanstvenog kolokvija: Svećenici glagoljaši i njihova ostavština, Zadar (u tisku).

Franov-Živković, Grozdana, Život i djelo glagoljaša don Jerolima Kuzmića Šimića (župa Sutomišćica, oko 1726. - 4.12.1793.), Croatica Christiana Periodica, br. 75, godina XXXIX, Zagreb, 2015., 89 - 102.

Franov-ŽIvković, Grozdana, Fatevićev zbornik duhovnog štiva, 1617., Riznica glagoljaške kulture i hrvatske pismenosti otoka Rave, niz Monumenta glagolitica Archidioecesis Iadertianae, ur. Pavao Kero, Blaga Bunčuga i Josip Faričić, Zadar, 2016.

Franov-Živković, Grozdana, Glagoljske moralno-kazuističke odredbe ninskih biskupa 17. i 18. st., Radovi Zavoda za povijesne znanosti Hrvatske akademije znanosti $i$ umjetnosti u Zadru, 57, Zagreb-Zadar, 2015., 185 - 216.

Franov-Živković, Grozdana, Bobanović, Mate, Povijesna demografija Starigrada na temelju matičnih knjiga iz 19. stoljeća i glagoljskih i ostalih dokumenata nastalih u razdoblju od kraja 17. do sredine 19. stoljeća, Zbornik sa Znanstveno-stručnog skupa Starigrad-Paklenica (u tisku). 
Franov-Živković, Grozdana, Bobanović, Mate, Povijesna demografija Selina na temelju matičnih knjiga iz 19. stoljeća i glagoljskih i ostalih dokumenata nastalih u razdoblju od kraja 17. do sredine 19. stoljeća, Zbornik sa Znanstveno-stručnog skupa Starigrad-Paklenica (u tisku);

Franov-Žıvnović, Grozdana, Bobanović, Mate, Povijesna demografija Tribnja na temelju matičnih knjiga iz 19. stoljeća i glagoljskih i ostalih dokumenata nastalih u razdoblju od kraja 17. do sredine 19. stoljeća, Zbornik sa Znanstveno-stručnog skupa Starigrad-Paklenica (u tisku).

Franov-Žıvković, Grozdana, Društveni položaj pripadnika mletačkih teritorijalnih snaga (černida) sa zadarskog područja u 17. i 18. stoljeću na temelju glagoljskih matičnih knjiga i ostalih dokumenata, Acta Histria, 26, Koper, 2018., 473 - 502.

JELINČIĆ, Jakov, Dnevnik rada popisivanja gradiva crkvenih arhiva porečke i pulske biskupije te pazinske apostolske administrature (18. prosinca 1970. 28. listopada 1980), Vjesnik istarskog arbiva, svezak 25, 2018., 49 - 99.

Kapetanović, Vicko, Skradinski biskupi i građevine u porječju Krke u 18. stoljeću prema arhivskim spisima, Titius, god 1, br. 1, 2008., 33-52.

Kero, Pavao, Popis glagoljskih kodeksa Zadarske nadbiskupije, drugo izdanje, Zadar, 2015.

Kero, Pavao, Leksikon svećenika Zadarske nadbiskupije (u rukopisu).

Kero, Pavao, Franov-Žıvković, Grozdana, Perović, Milan, Biogradska glagoljska madrikula Bratovštine Uznesenja Blažene Djevice Marije 1720. 1841., Zadar, 2012.

PERIČić, Šime, Gospodarska povijest Dalmacije od 18. do 20. stoljeća, Zadar, 1998.

Pet Ricioli, Ivo, Stalna izložba crkvene umjetnosti u Zadru, ur. Antun Travirka, Zadar, 2004.

PeZELJ, Vilma, Žene u bratovštinama srednjovjekovnih dalmatinskih gradova, Zbornik radova Pravnog fakulteta u Splitu, god. 47, br.1 (95), Split, 2010., $155-173$.

RunJe, Petar, Glagoljica u zadarskoj nadbiskupiji u srednjem vijeku, Zadar, 2005.

Runje, Petar, Duhovni život na zadarskim otocima u kasnome srednjem vijeku, Zadar, 2008.

RunJe, Petar, O knjigama hrvatskih glagoljaša, Zagreb, 1997.

ŠTEFANIĆ, Vjekoslav, Glagoljski rukopisi Jugoslavenske akademije II, Zagreb, 1970. 
Veronese, Fabiana, Terra di nessuno. Misto foro e conflitti tra Inquisizione e magistrature secolari nella Repubblica di Venezia (XVIII sec.), doktorski rad, Venecija 2010. (dspace.unive.it > handle>, posjećeno 17. 2. 2020.)

Vodič arhiva Zadarske nadbiskupije, prir. Oliver Modrić i Josip Kolanović, Zadar, 2013.

Vodič Državnoga arhiva u Zadru, ur. Josip Kolanović, Zadar, 2014., knjiga II. 
Grozdana FRANOV-ŽIVKOVIĆ

\author{
GLAGOLITIC MADRICULA OF THE PRIESTLY \\ BROTHERHOOD OF THE ZADAR ISLANDS OF THE LORD'S \\ SUPPER (COENA DOMINI) FROM UGLJAN FROM THE EARLY \\ 17TH TO THE EARLY 19TH CENTURY
}

SUMMARY

In the Zadar area in the past, we find several priestly brotherhoods, a bit more lay (religious and craft), and a bit fewer priestly ones. Most of these fraternities have not been dealt with so far. Their number, goals and tasks, but also the period of activity are not precisely defined. At the beginning of the article, the number of priestly brotherhoods in the Zadar area is determined. In Zadar, we find eight priestly brotherhoods, on the islands there were six, and on the mainland four. The article will place particular emphasis on the island brotherhood of the Lord's Supper from Ugljan, its goals and tasks based on the Glagolitic madricula recently found in Trieste. The association was founded (or renewed) in 1617. The members of this fraternity were priests from the northwestern part of the island of Ugljan, primarily from the towns of Ugljan, Lukoran, Sutomišćica, Poljana and Preko and in part priests from the islands of Olib, Molat, Iž, Premuda, Silba, Vir and the northwestern part of Dugi Otok. The madricula comprises 31 chapters, lists of priestly brothers, and a small number of lay people (mostly landowners, landlords, village heads, and captains). Two archbishops of Zadar and one bishop of Skradin, a native of Zadar, were also members of the fraternity. The last records date back to 1816. A group of the priests whose Glagolitic collections of texts have been preserved to this day also belonged of this brotherhood.

Keywords: priestly brotherhoods, Glagolitic madriculas, Ugljan, Fraternity of the Lord's Supper, early 17 th to early 19 th century. 